\title{
Bicameralismo e Poder Executivo no Brasil: revisão de projetos presidenciais entre 1989-2010
}

\author{
\begin{tabular}{c}
\hline \hline Paulo Magalhães Araújo \\
Programa de Pós-Graduação em Ciências Sociais \\
Universidade Federal do Espírito Santo \\
\hline \hline
\end{tabular}
}

Resumo: $O$ artigo investiga o desempenho do Senado brasileiro tendo em vista o arranjo bicameral vigente. Sendo o Senado quase sempre revisor, e sendo o emendamento um indicador objetivo da atuação em revisão, o artigo analisa as variáveis que influenciam os senadores a emendar os projetos revisados. Supõe-se que os senadores não são meros "carimbadores", nem tampouco são recalcitrantes no uso de seus poderes de veto. A hipótese geral é que as escolhas dos senadores são condicionadas por variáveis como a configuração bicameral da representação, a posição da Casa na cadeia decisória e a origem dos projetos de lei. Em linhas gerais, notou-se que o bicameralismo brasileiro minimiza as chances de conflito no Senado; no entanto, notou-se que certas variações na composição da coalizão e no grau de divergência bicameral das forças partidárias acentuam a disposição dos senadores para emendar os projetos que tramitam na Casa.

Palavras-chave: bicameralismo; Senado; Poder Executivo; comportamento parlamentar

Abstract: This article investigates the performance of the Brazilian Senate in light of the current bicameral structure. Since the Senate is almost always a reviewing body, and since amendments are an objective indicator of its role in revision, the article analyzes the variables which influence senators to amend the projects which are reviewed. It is assumed that the senators are not merely "rubber-stamping" projects, nor are they recalcitrant about using their veto powers. The general hypothesis is that the senators' choices depend on variables such as the bicameral configuration of representation, the position of the House in the decision-making process, and the origin of the legislation. Along general lines, it was noted that bicameralism in Brazil minimizes the chances of conflict in the Senate; however, it was noted that certain variations in the composition of coalitions and in the degree of bicameral divergence of party forces accentuate senators' willingness to amend the projects that come before the House.

Keywords: bicameralism; House; Executive Branch; parliamentary behavior 


\section{Apresentação ${ }^{1}$}

Entre as características de um sistema político, a estrutura do Poder Legislativo merece destaque. Parlamentos unicamerais geram, em tese, menos custos para o processo decisório, porque implicam um ponto de veto a menos (TSEBELIS, 1995; TSEBELIS e MoneY, 1997). Os parlamentos bicamerais, por sua vez, se assemelham aos unicamerais quando a segunda câmara é desprovida de poder político ou é composta pelos mesmos métodos que a primeira (TSEBELIS e MONEY, 1997). No entanto, quando as regras de composição das duas Casas são incongruentes entre si e quando as atribuições e prerrogativas políticas são distribuídas simetricamente entre elas o Legislativo é, efetivamente, bicameral, isto é, composto por dois veto players institucionais.

Este é o caso do Brasil. Entre os especialistas, há grande polêmica em torno das interpretações sobre o sistema político brasileiro e suas consequências no processo decisório, mas neste ponto parece haver consenso: o Senado Federal é uma das segundas câmaras mais potentes do mundo, devido aos altos graus de incongruência e de simetria do bicameralismo no Brasil (LLANOS E NOLTE, 2003; LLANOS, 2003).

Em relação à simetria, conforme previsto nos art. 52 a 70 da Constituição Federal de 1988 (CF-88), os senadores têm enorme poder para interferir nas questões do governo, tanto no que respeita à produção normativa, quando no tocante ao controle constitucional das autoridades públicas. Especificamente em relação à produção normativa, a Constituição vigente atribui aos senadores o direito exclusivo de tomar decisões no interesse dos estados e municípios relativamente ao endividamento público e a questões territoriais, e tem, ainda, o direito concorrente, frente à Câmara e ao Executivo, de iniciar a tramitação de projetos voltados aos mais variados interesses da sociedade. No campo da produção de leis - foco principal da análise deste artigo -, além de poderem iniciar a tramitação de projetos, os senadores podem atuar reativamente, como revisores das matérias já aprovadas pelos deputados, quer tenham elas sido apresentadas pela Câmara, pelo Executivo, pelo Judiciário ou pelos cidadãos. Como órgão revisor, o Senado pode alterar o conteúdo das matérias que aprecia: na Casa podem ser apresentados projetos alternativos (substitutivos) ou mesmo "vetos" totais ou parciais às propostas em revisão. Importa ressaltar, ademais, que o poder legiferante do Senado abrange todo tipo de questão política de interesse nacional, muito embora ele seja, formalmente, a Casa de representação das unidades federadas, não do povo brasileiro como um todo.

Em relação à incongruência, suas bases são estabelecidas nos art. 44 a 46 da CF.88, que definem as regras eleitorais e o tempo de mandato para senadores e deputados - eleições majoritárias, com mandatos de oito anos e renovação intercalada para aqueles e eleições proporcionais, com mandatos de quatro anos e renovação total para estes. Há também o art. 14, que exige diferentes idades para acesso aos cargos de senador (35 anos) e deputado (21 anos). Na medida em que fomenta distinções entre os perfis parlamentares e entre as estruturas de interesse de uma casa frente à outra, a incongruência consiste em incentivo ao uso dos poderes simétricos, estimulando, enfim, a função de veto player na estrutura bicameral.

\footnotetext{
${ }^{1}$ Este artigo desdobra-se da Tese de Doutorado do autor e é resultado parcial de projeto de pesquisa sobre o Senado Federal e o bicameralismo no Brasil, com apoio financeiro do CNPq e da Fundação de Amparo à Pesquisa do Espírito Santo (Fapes). $\mathrm{O}$ autor agradece as valiosas críticas e sugestões dos pareceristas anônimos da Revista Opinião Pública.
} 


\section{ARAÚJO, P. M. Bicameralismo e Poder Executivo no Brasil: revisão de projetos...}

Há uma complexidade a mais, de natureza institucional, relacionada ao bicameralismo brasileiro. As questões analíticas atinentes ao desempenho da Segunda Câmara extrapolam a temática da estrutura do Poder Legislativo e tocam a questão do sistema de governo como um todo. O Senado é uma instância decisória aninhada numa estrutura institucional mais ampla, cuja característica mais evidente é a pluralidade e a fragmentação do poder, que amplia o escopo dos consensos e aumenta as dificuldades para a tomada de decisões de interesse geral. Assim, para entender adequadamente o desempenho do Senado, é preciso considerá-lo em face dos traços mais abrangentes do sistema político.

Para alguns especialistas (AMES, 2001; MAINWARING, 1997; 2001; LINZ, 1994), a combinação institucional do presidencialismo brasileiro resulta num padrão decisório inviável, porque dá excessivo poder de veto às minorias, fragmenta demais o poder político e incentiva estratégias centrífugas, levando à competição entre forças políticas que, para o bem do país, deveriam se coalizar. Segundo Mainwaring, a combinação do presidencialismo com um sistema multipartidário fragmentado, partidos indisciplinados, bicameralismo forte e um federalismo robusto resulta em dificuldades frequentes ao governo (MAINWARING, 1997, p. 56). Com isso, as expectativas quanto ao resultado do jogo político não poderiam ser piores: irracionalidade alocativa, processos de governo truncados e entraves constantes.

Em contraponto a essa visão, há os que entendem que as causas da fragmentação do poder político - a baixa coesão dos agentes coletivos combinada com um arranjo institucional dito explosivo . encontram seu antídoto no padrão de relação entre Executivo e Legislativo e também no modelo de organização interna do Congresso Nacional (FIGUeIREdo E LIMONGI, 1996; 1999; MENEGUELLO, 2002; SANTOS, 2003). Os pesquisadores dessa linha de investigação argumentam que, na prática, o processo decisório é conduzido pelo Executivo e pelas lideranças partidárias. Isso reduziria o potencial centrífugo do sistema, concentrando poderes em poucos atores, tornando-os capazes de articular acomodações de interesses e consensos entre as forças políticas relevantes. Dessa perspectiva, o todo é algo mais que a soma das partes, ou seja, o conjunto das instituições resolve os problemas de ação coletiva suscitados por instituições isoladas, promovendo um padrão decisório razoavelmente estável, ágil e eficaz para o processamento das demandas apresentadas ao sistema político.

No que importa à questão central deste artigo, essa polêmica teórica evidencia um componente do sistema decisório cuja importância é consenso entre os especialistas: a coalizão de governo. Alguns críticos questionam o quanto as coalizões são bases de apoio disciplinadas e confiáveis, ou questionam se os ganhos de capacidade governativa que elas propiciam compensam, de fato, os custos envolvidos na sua formação e manutenção por parte do Executivo. No entanto, a partir do estudo de Abranches (1988), não se coloca em dúvida a pertinência do termo "presidencialismo de coalizão" para designar o modus operandi do sistema de governo vigente no país.

Num contexto decisório onde o governo se sustenta, bem ou mal, sobre o apoio parlamentar de uma coalizão de partidos, tendo em vista o bicameralismo simétrico e incongruente em vigor no país, o caráter bicameral da coalizão consiste num fator de relevo para o entendimento da dinâmica decisória. Surpreendentemente, tal fator tem sido ignorado ou relegado a segundo plano nas pesquisas empíricas sobre o tema, prejudicando a compreensão da influência do Senado no desempenho do Congresso em geral, e no desempenho das coalizões de governo em particular. 
O acima exposto evidencia uma característica importante dos sistemas presidenciais de coalizão, que os distingue dos sistemas bipartidários como o dos Estados Unidos. Estes propiciam os chamados governos divididos, isto é, situações em que o Executivo, o Senado e a Câmara não são controlados pelo mesmo partido (MAYHEW, 1991; TSEBELIS, 1995). Em contexto bipartidário, dados os resultados eleitorais, as possibilidades de reconfiguração do equilíbrio de forças partidárias durante os mandatos são muito restritivas. Diferentemente, no presidencialismo de coalizão brasileiro, o padrão de interação Executivo-Legislativo depende fortemente das negociações partidárias após as eleições (ANDRADE, 1998; ANASTASIA E INÁCIO, 2008; INÁCIO E NUNO, 2005), sendo que o presidente tem amplas condições para promover o reposicionamento dos partidos em relação ao governo. O monopólio do Executivo sobre medidas orçamentárias e cargos públicos - além de outros recursos e prerrogativas constitucionais -, associado à multiplicidade dos possíveis parceiros legislativos, propicia um grau de mobilidade dos partidos nas posições "governo" e "não-governo" improvável em sistemas bipartidários como o dos EUA.

O fato é que os traços do sistema brasileiro fazem do Executivo um centro de poder muito atrativo para os partidos no parlamento, de modo que uma situação na qual a coalizão presidencial é minoritária em uma casa, ou nas duas, depende não só dos resultados eleitorais, mas, em grande medida, dos interesses e estratégias do presidente da República durante o governo. Em outras palavras, os constantes esforços do Executivo para construir e manter coalizões de apoio são decisivos para a interação do governo com o Legislativo, de tal modo que as estratégias de cooperação ou de veto adotadas em cada Casa são influenciadas pelos esforços coalizacionais do chefe do Executivo.

Dado esse complexo arcabouço institucional, coloca-se a questão: qual o efetivo papel do Senado brasileiro nas decisões do governo federal? Ele é um obstáculo às decisões políticas de interesse nacional ou um mero coadjuvante nos acordos travados entre o Senado e as demais instâncias dotadas do direito de iniciativa legislativa?

Essa é uma divergência em destaque na literatura sobre a questão. De um lado, há autores que enfatizam a simetria e a incongruência do bicameralismo brasileiro e preveem um comportamento obstrutivo do Senado, agravando os custos para a tomada de decisões na já complexa estrutura do presidencialismo de coalizão (BACKES, 1999; 2008; STEPAN, 1999; MAINWARING, 2001); de outro lado, Figueiredo e Limongi (1999; 2008) e autores afins ressaltam as bases partidárias da organização parlamentar e a centralização decisória daí decorrente para argumentar que os fatores de obstrução decisória - o Senado, inclusive - são superados pelos poderes de agenda dos líderes partidários e do Poder Executivo.

Ambos os pontos de vista são esclarecedores da posição do Senado no sistema político brasileiro. Mas, nem tanto ao céu nem tanto à terra: a resposta à questão não deve supor que as prerrogativas institucionais dos senadores se convertem "naturalmente" em recalcitrante postura de veto, como sugerem alguns especialistas, nem tampouco que o Senado é uma casa subserviente ou pouco expressiva nas decisões bicamerais, como sugerem outros. Os senadores, como atores racionais, fazem uso dos recursos político-institucionais disponibilizados pelo arranjo institucional do país. Porém, defende-se aqui, como hipótese geral, que sua escolha pela cooperação ou pela obstrução é estratégica e, portanto, condicionada - por variáveis tais como a estrutura da coalizão, o tipo de legislação em 


\section{ARAÚJO, P. M. Bicameralismo e Poder Executivo no Brasil: revisão de projetos...}

apreciação, o regime de tramitação, o conteúdo das matérias, o quórum exigido para sua aprovação, etc. Essas variáveis são fortemente afetadas pelas estratégias do Poder Executivo, que escolhe quais projetos submeterá ao Congresso e define, ademais, as estratégias de construção de apoio parlamentar. Esperase que o tratamento dado pelos senadores às matérias do governo guardem relações com tais variáveis.

$\mathrm{Na}$ análise aqui proposta, a alteração dos projetos do Executivo durante a tramitação no Senado - através de emendas de mérito ou de substitutivos - é tomada como variável dependente e considerada como um indicador de ativismo decisório dos senadores em relação ao governo. Tendo por base a tramitação de 827 projetos (PECs, PLPs e PLs) ${ }^{2}$ aprovados na Casa entre 1989 e 2010, a pesquisa analisa o desempenho legislativo do Senado no tocante às taxas de emendamento das matérias do Executivo submetidas à revisão senatorial.

Sustentado nessa produção legislativa, o objetivo é identificar e mensurar o peso de variáveis hipoteticamente associadas à disposição dos senadores para utilizarem seu direito de reformular os projetos por meio de emendas ou substitutivos. Com isso, o estudo visa apresentar uma análise empírica que vá além das visões polares sobre o Senado brasileiro, explicitando a natureza condicional do seu desempenho legiferante, de modo a qualificar melhor sua atuação como instância decisória.

$\mathrm{O}$ artigo tem cinco seções, incluindo esta introdução e as considerações finais. A próxima seção compara a composição política do Congresso, considerando o perfil da representação tanto em termos da composição geral das Casas quanto em termos da estrutura das coalizões, em escala bicameral. 0 objetivo é avaliar se, e de que forma, as variações na representação podem afetar o comportamento dos senadores no processo legiferante. Tendo por base as configurações políticas delineadas na segunda seção, a terceira apresenta algumas conclusões sobre os impactos esperados do perfil da representação bicameral e da estrutura das coalizões no desempenho legislativo do Senado. Com base nos dados, argumenta-se que a Segunda Câmara do Congresso Nacional tende a apresentar uma composição política mais estável e menos heterogênea do que a primeira, propiciando condições mais favoráveis para a produção de consensos, especialmente em relação a propostas do governo. Com isso, entende-se, em parte, por que o Senado pode parecer uma arena decisória pouco propensa à obstrução política, embora disponha de poder de veto para tal. Na quarta seção são feitos os testes de hipóteses, com modelos de regressão logística. $\mathrm{O}$ emendamento dos projetos do Executivo foi escolhido como variável dependente $^{3}$ indicadora do ativismo político dos senadores. Isso posto, testam-se os efeitos da composição político-partidária do Senado - em si mesmo e em relação à Câmara - sobre as chances de um projeto ser emendado no processo de revisão senatorial.

O teste de hipóteses leva em conta a duração e a composição das coalizões de governo atuantes no período. As coalizões definem intervalos temporais claramente delimitados, com traços políticos próprios, que servirão de referência para a análise da pertinência das hipóteses em vista. Espera-se que o tamanho, a abrangência ideológica, o número efetivo de partidos da coalizão (NEPC), bem como o grau de divergência bicameral intracoalizão, afetem o desempenho do Senado no tocante a

\footnotetext{
2 Respectivamente: propostas de emenda constitucional, projetos de lei complementar e projetos de lei ordinária. Para fins de controle dos testes estatísticos, do total de propostas aprovadas no período (827) selecionaram-se apenas as que ingressaram no Senado e foram aprovadas sob uma mesma coalizão. Por isso, o número de projetos incluídos no teste de hipóteses se reduz, como se verá adiante.

${ }^{3}$ Trata-se de variável dummy, ou binária, que indica se o projeto foi ou não emendado. Esta escolha metodológica será explicada adiante.
} 
projetos de interesse do governo. Controlando-se outras variáveis relevantes, as variações na representação política devem impactar significativamente a probabilidade de um projeto ser alterado. Em termos mais específicos: a relação esperada entre o tamanho da coalizão e as chances de emendamento é negativa, isto é, controladas as demais variáveis relevantes - a serem apresentadas oportunamente -, as coalizões majoritárias reduzem as chances de um projeto ser emendado no Senado; a relação entre os demais indicadores e o emendamento é positiva, tal que quanto maiores a abrangência ideológica da coalizão, o NEPC e a divergência bicameral da coalizão, maiores as chances de os projetos serem alterados pelos senadores. Ao teste de hipóteses seguem as conclusões do artigo.

\section{De Sarney a Lula: legislaturas, coalizões, governos e as bases políticas da atuação dos senadores}

Devido ao caráter condicional do comportamento estratégico e à natureza estratégica da atuação parlamentar, as escolhas feitas pelos senadores no processo decisório bicameral não podem ser compreendidas sem uma análise dos incentivos institucionais e políticos presentes nos contextos de ação. Incentivos institucionais e políticos se interconectam, não são sinônimos ${ }^{4}$. Nos termos aqui adotados, os incentivos institucionais são aqueles relacionados à "estática" do ambiente decisório, são as chamadas regras do jogo, no sentido de Tsebelis (1998) - regras que, como tais, são externas às escolhas, a menos que um jogo de mudança institucional tenha início, tornando-as objetos de escolha. Os incentivos políticos, diferententemente, estão relacionados à "dinâmica" do ambiente decisório, isto é, a processos de formação e organização de preferências decorrentes - em geral, mas não exclusivamente - das disputas eleitorais e do jogo parlamentar.

O padrão de comportamento parlamentar engendrado pela estrutura institucional do sistema decisório brasileiro é abordado em uma ampla e crescente literatura, embora a cota de estudos voltados ao Senado seja pequena frente à existente sobre a Câmara dos Deputados. A despeito dessa defasagem, é possível afirmar que, por um lado, a incongruência bicameral induz à formação de um leque diferenciado de interesses no Senado, se comparado com as demais instâncias decisórias (STEPAN, 1999; DESPOSATO, 2002; 2006; HIROY, 2008), por outro, a simetria do sistema provê aos senadores os instrumentos propícios para a afirmação oportuna de seus interesses (HIROY, 2008; ARAúJO, 2012).

Este artigo põe foco na dimensão política do ambiente decisório federal e nas suas potenciais consequências sobre escolhas dos senadores no período 1989-2010. A opção analítica está relacionada à hipótese de que o uso que os senadores fazem dos instrumentos formais a sua disposição é condicionado pela composição dos interesses e pelo equilíbrio de forças no plano federal, decorrentes, em grande medida, dos processos políticos intra e extracongressuais. As páginas seguintes apresentam um panorama da composição político-partidária do Congresso Nacional no período em foco, com vistas a revelar as bases de interação entre os senadores e as demais instâncias do sistema decisório.

\section{Senado e Câmara: a composição partidária do Congresso Nacional de 1989 a 2010}

Entre os diversos elementos institucionais que promovem a incongruência do bicameralismo brasileiro destacam-se as regras eleitorais, por seus efeitos na composição partidária do Legislativo. A

\footnotetext{
${ }^{4}$ Os aspectos institucionais do sistema político influenciam a configuração política dos interesses, estes, por sua vez, podem engendrar um jogo de mudança institucional (TSEBELIS, 1998) quando os resultados gerados pela matriz institucional contrariam reiteradamente os interesses dos atores que conduzem o processo decisório.
} 


\section{ARAÚJO, P. M. Bicameralismo e Poder Executivo no Brasil: revisão de projetos...}

adoção de representação majoritária para o Senado e proporcional para a Câmara dos Deputados tende a produzir diferentes configurações partidárias, incrementando a representação política e potencializando os controles horizontais do sistema, seja entre Legislativo e Executivo, seja entre Senado e Câmara.

Se, por um lado, a incongruência das regras para o acesso às Câmaras Alta e Baixa tende a redundar em controles mútuos de natureza partidária, por outro, o aspecto partidário do bicameralismo é reforçado pelos modelos de organização legislativa que vigem no Congresso desde a promulgação da atual Constituição (FIGUEIREDO E LIMONGI, 1999; 2008).

Embora haja variações importantes entre as organizações internas do Senado e da Câmara, elas não invalidam os fundamentos partidários de qualquer das Casas. Duas diferenças merecem destaque: a primeira é a ausência de um colégio de líderes no Senado, tal como existe na Câmara; a outra, talvez decorrente desta, é que o regimento do Senado prevê menos prerrogativas de suas lideranças na elaboração da agenda parlamentar, centralizando no presidente da Casa essa atribuição (ARAúJo, 2009; MIRANDA, 2010; NEIVA, 2011). Isso não significa, no entanto, a despartidarização do Senado, em primeiro lugar, porque seu presidente, conforme aponta a literatura pertinente, é escolhido partidariamente e de fato atua como agente partidário ou de coalizões partidárias, em segundo lugar, porque o silêncio regimental sobre alguns poderes de agenda dos líderes senadores não os destituem de influência sobre as decisões parlamentares. Análises recentes da produção legislativa do Congresso Nacional mostram que, assim como na Câmara, os líderes no Senado controlam eficazmente o comportamento parlamentar, bem como o timing e o conteúdo das decisões, através de recursos como a orientação de votação (ARAúJo, 2009; SIMÃo Branco, 2008; MIRANDA, 2009; 2010; NEIVA, 2011$)^{5}$ e o requerimento de urgência (ARAúJO, 2009; 2012; MIRANDA, 2009; 2010).

Nestes termos, é possível sustentar que, a despeito das variações, o funcionamento de ambas as Casas se assenta nos partidos. O fato é que esse padrão organizacional, combinado com a incongruência bicameral dos processos eleitorais, transforma as representações partidárias em variáveis centrais na interpretação do funcionamento bicameral no Brasil.

O impacto das regras eleitorais sobre a estrutura da representação política é bastante debatido na literatura. Desde as chamadas "leis de Duverger", postuladas na década de 1950, há grande discussão sobre os efeitos dos tipos de sufrágio na conformação do sistema partidário e da representação parlamentar. Em termos gerais, argumenta-se que, devido aos efeitos mecânicos e psicológicos das normas de competição eleitoral, as eleições majoritárias de turno único induzem ao bipartidarismo, ao passo que as majoritárias de dois turnos e as eleições proporcionais, em distritos de grande magnitude, fomentam o multipartidarismo (DUVERGER, 1980; NICOLAU, 1999).

No caso do Congresso Nacional, ainda que as disputas eleitorais para as duas Casas estejam sujeitas a incentivos institucionais comuns - como a estrutura federativa do país e as eleições

\footnotetext{
${ }^{5}$ Diversos autores analisaram votações nominais na Câmara e no Senado, comparando os níveis de disciplina de senadores e deputados. Simão Branco (2008) considerou votações nominais sobre emendas constitucionais de impacto federativo e percebe maior índice de disciplina entre os senadores; Miranda (2010), Neiva (2011) e Melo e Batista (2012), com dados de votações nominais de um largo período, mostraram que, nas duas Casas, os percentuais de adesão aos partidos estão praticamente nos mesmos patamares. Araújo (2009) estudou tramitações de projetos de lei no Senado, iniciados no período 1989-2004, e mostrou que $58 \%$ das urgências foram requeridas exclusivamente pelos líderes, que, ademais, compartilharam a autoria da urgência com outros atores, como o Executivo, cujos requerimentos unilaterais de urgência são, muitas vezes, "reforçados" por urgência de lideranças quando chegam no Senado.
} 
presidenciais de dois turnos - é possível esperar que as distintas formas de representação adotadas para Câmara e Senado tenham impacto sobre as respectivas configurações partidárias ${ }^{6}$, ou seja, resultem em diferentes cenários políticos nos quais deverão se dar as negociações, quer entre senadores e deputados, quer entre parlamentares e o Executivo. O Gráfico 1 mostra um fenômeno devido, em grande parte, às regras eleitorais: a reiterada diferença entre as Casas no tocante aos números nominais e efetivos de partidos políticos.

Gráfico 1

\section{Evolução do NEP na Câmara e no Senado (1989-2010)}

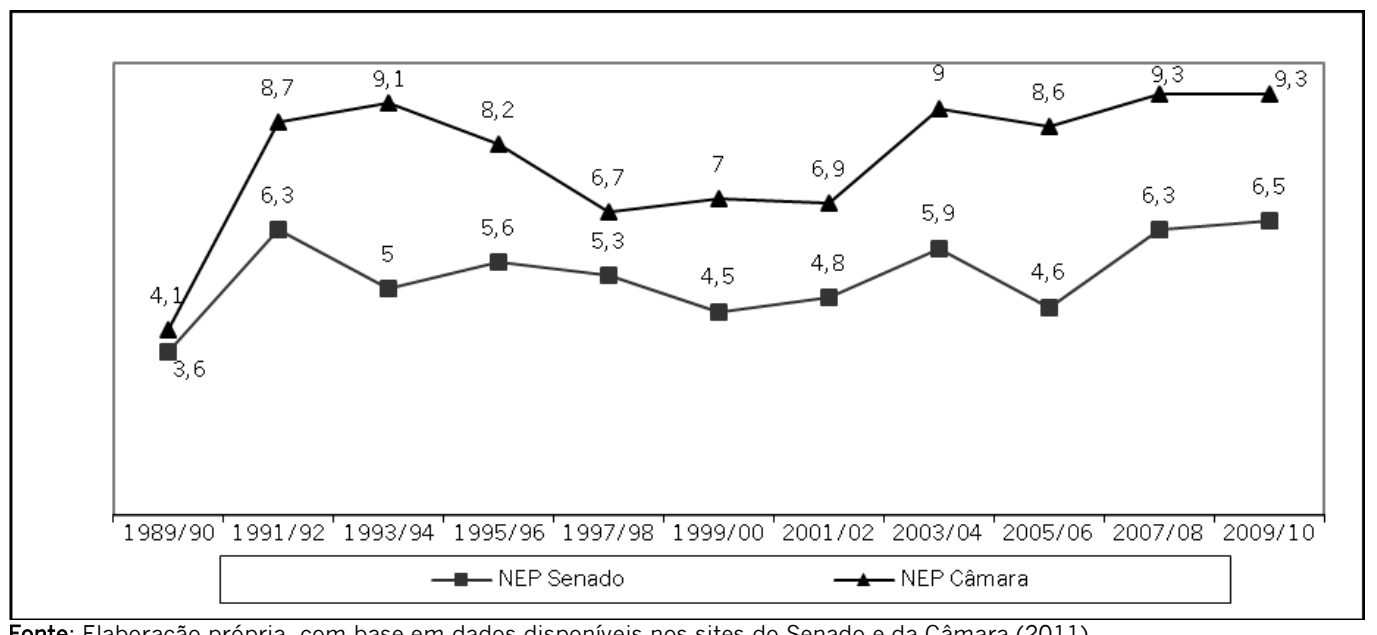

Fonte: Elaboração própria, com base em dados disponíveis nos sites do Senado e da Câmara (2011).

Não se podem desconsiderar fatores extraeleitorais que alteram a composição partidária das legislaturas e, portanto, podem interferir na taxa de divergência. Como exemplos, vale destacar a criação, o desaparecimento ou fusão de legendas (NICOLAU, 1999) e a migração partidária (MELO, 2004). Sem dúvida, parte das diferenças intercamerais observadas no período se deve a ocorrências dessa natureza, porém, é plausível supor que a incongruência nas eleições é um fator de destaque, talvez o mais decisivo, para as diferenças partidárias observadas entre as Casas $^{7}$.

Qualquer que tenha sido a contribuição dos fatores adjacentes às regras eleitorais, produziu-se no período uma consistente incongruência na representação bicameral. O Senado foi menos marcado pela fragmentação partidária, fato sugestivo de que as eleições majoritárias, mais que as proporcionais, favorecem as maiores legendas e dificultam a ascensão política dos pequenos e micropartidos,

\footnotetext{
${ }^{6}$ Reynoso (2010), em estudo comparado de nove países da América Latina, incluindo o Brasil, confirma os efeitos dos sistemas eleitorais sobre a conformação da representação bicameral.

7 Embora as regras para a migração partidária e a fusão ou criação de partidos sejam nacionais e, portanto, idênticas para senadores e deputados, variáveis intervenientes, tais como o tamanho das Casas e o padrão de relação entre parlamentares e partidos em cada Casa, podem afetar o padrão de migração ou impacto da fusão ou criação de partidos em cada Casa. Sendo assim, as variáveis intervenientes mencionadas, e provavelmente outras, tornam-se relevantes fatores de incongruência, porém, a falta de estudos com esse foco não permite no momento mensurar seus efeitos, nos termos em que se pode mensurar o efeito das eleições sobre a incongruência, como a literatura tem mostrado. Reynoso (2010), em estudo comparado sobre países latino americanos, afirma que "la presencia de sistemas electorales alternativos en cada cámara tiende a producir composiciones partidarias distintas entre las cámaras" (Reynoso, 2010, p.81). Em relação ao caso brasileiro, Araújo (2012) analisa o perfil de candidatos eleitos e não eleitos ao Senado e conclui que as regras eleitorais geram incongruência partidária, entre Câmara e Senado, não apenas no contingente de eleitos, mas também dos candidatos em geral.
} 


\section{ARAÚJO, P. M. Bicameralismo e Poder Executivo no Brasil: revisão de projetos...}

propiciando a redução do número de partidos parlamentares. No período, a diferença entre o número de partidos nominais da Câmara e do Senado foi, em média, 6,6 (Câmara: 17,2 . Senado: 10,6) e a diferença do número efetivo de partidos (NEP), entre as duas Casas foi, em média, 2,5 (Câmara: 7,8 . Senado: 5,3). Esses dados convergem com o apontado na literatura (REYNOSO, 2010; ARAújo, 2012), isto é, indicam que a incongruência formal do sistema produz efetiva discrepância entre as Casas no tocante à estruturação partidária - tendo, por suposto, implicações sobre os custos envolvidos nos acordos políticos bicamerais.

O NEP, como se sabe, é um indicador bastante utilizado para avaliar a competitividade partidária, seja na arena eleitoral seja na parlamentar. Na esfera legislativa, o suposto é que quanto maior o NEP mais consensual o sistema (LIJPHART, 2003), isto é, maior o número de atores relevantes com quem se deve negociar a aprovação de políticas. Dessa perspectiva, o Senado e a Câmara apresentaram no período em foco distintos horizontes para a formação de acordos em torno de questões a serem votadas.

Nota-se no Gráfico 1 que na composição senatorial houve menor variação no NEP, indicando que, ao menos em relação ao número de partidos, o Senado é uma arena de composição partidária mais estável, onde a formação de maiorias tende a envolver um número menor de atores relevantes. Por suposto, as negociações nessa Casa implicam menos custos decisórios. Porém, isso não anula a relevância da variação longitudinal do período, seja no valor do NEP em cada Casa, seja na distância entre os valores de uma casa e outra. Tendo em vista a importância dos partidos no funcionamento do Legislativo destacada por uma ampla literatura, é plausível supor que tal variação se expresse, ao longo do tempo, em diferentes padrões de tramitação das propostas no Senado.

Além do número nominal ou efetivo de partidos, as regras eleitorais afetam também o peso de cada partido em cada Casa, reforçando o grau de divergência da representação bicameral. Se um efeito esperado do bicameralismo incongruente é a criação de diferentes situações de negociação no processo legislativo, as discrepâncias intercamerais no tamanho das bancadas partidárias são dados a serem considerados. Em tese, quanto maiores as diferenças, maiores as bases para a divergência de opiniões, que deverão ter implicações, por exemplo, no tempo de tramitação dos projetos e na probabilidade de que sejam emendados. 
Gráfico 2

Taxas de divergência bicameral total e interblocos (1989-2010)

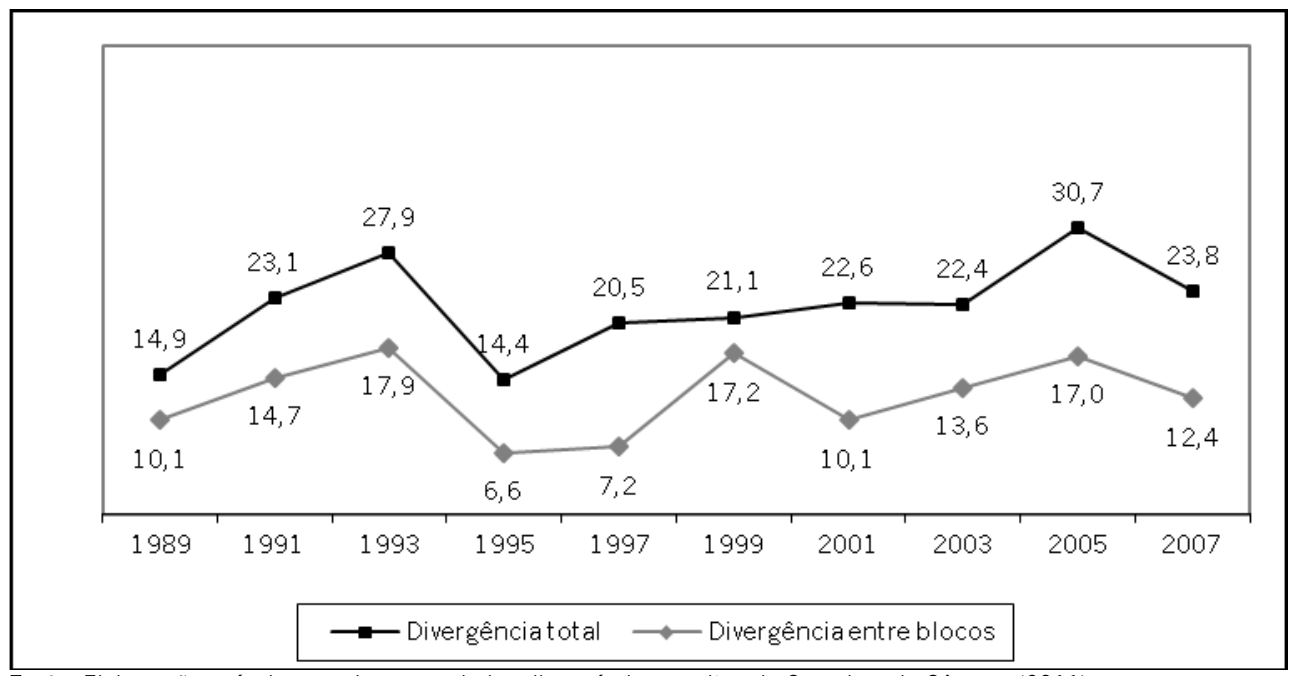

Fonte: Elaboração própria, com base em dados disponíveis nos sites do Senado e da Câmara (2011).

O Gráfico 2 revela as variações nos índices de divergência bicameral ${ }^{8}$ total e divergência entre blocos ideológicos, que se deram no Congresso entre 1989 e 2010. O índice adotado varia de 0 a 100 . "Zero" indica coincidência total, ou seja, uma situação hipotética em que, nas duas Casas, os mesmos partidos têm bancadas percentualmente idênticas; "cem", ao contrário, designa discrepância total, isto é, indica que os partidos representados em uma Casa estão totalmente ausentes da outra.

A linha superior do gráfico se refere às taxas de divergência calculadas com base nas bancadas partidárias. A média observada no período foi de 22,3, mas notam-se alterações expressivas ao longo do tempo: de 14,9 em 1990 a 30,7 em 2006, com queda para 24,3 em 2010. Os dados revelam que os processos eleitorais - e fatores adjacentes - produzem diferentes graus de divergência e, em tese, estabelecem padrões variados de incentivos para as relações entre Senado e Câmara, particularmente no tocante ao processo de produção de leis.

A linha inferior do gráfico expressa os índices de divergência bicameral entre os blocos ideológicos de esquerda, centro e direita. Em comparação com a divergência bicameral total, a divergência entre-blocos é notavelmente menor, com média de 12,7. Isso ocorre porque esta variação corresponde a apenas parte da variação global, já que as oscilações internas aos blocos são ignoradas no cálculo (BARTOLINE E MaIR, 1990).

\footnotetext{
$8 \mathrm{Na}$ literatura sobre bicameralismo, como neste artigo, o termo incongruência designa o método de constituição das Casas. Aqui, a expressão utilizada para designar as discrepâncias efetivas na composição das Câmaras será divergência bicameral na representação partidária ou, simplesmente, divergência bicameral. A divergência bicameral é calculada com base na fórmula de volatilidade eleitoral. A fórmula é a seguinte: $V E=\left[\left(P 1 \cdot P 1{ }^{\prime}\right)+(P 2 \cdot P 2 ')+\ldots\left(P n \cdot P n^{\prime}\right)\right] / 2$, em que $P$ corresponde à proporção de votos ou de cadeiras de cada partido e P', à proporção de votos ou de cadeiras obtidas por cada partido na eleição anterior. Ajustada à análise da taxa de incongruência bicameral da representação, a fórmula é: Divergência Bicameral (DB) = [(PS1-PC1)+(PS2. PC2) $+\ldots(P S n-P C n)] / 2$, em que PS corresponde à proporção de cadeiras de cada partido no Senado e PC à proporção de cadeiras de cada partido na Câmara.
} 


\section{ARAÚJO, P. M. Bicameralismo e Poder Executivo no Brasil: revisão de projetos...}

Num cenário partidário fragmentado como este, aceitando-se que a posição ideológica ${ }^{9}$ dos partidos é, em certas questões, um condicionante significativo do comportamento parlamentar, a incongruência bicameral de base ideológica pode estar relacionada de forma mais consistente que a partidária com o grau de (des)harmonia nas relações intercamerais. A Tabela 1 permite considerações adicionais sobre esta questão:

Tabela 1

Divergência bicameral intra e interblocos, por biênios $(1989-2010)^{*}$

\begin{tabular}{|c|c|c|c|c|c|c|c|c|c|c|c|c|}
\hline Blocos & $\begin{array}{l}1989 \\
1990 \\
\end{array}$ & $\begin{array}{l}1991 . \\
1992\end{array}$ & $\begin{array}{l}1993 \\
1994 \\
\end{array}$ & $\begin{array}{l}1995 \\
1996 \\
\end{array}$ & $\begin{array}{l}1997 . \\
1998 \\
\end{array}$ & $\begin{array}{l}1999 \\
2000 \\
\end{array}$ & $\begin{array}{l}2001 \cdot \\
2002\end{array}$ & $\begin{array}{l}2003 \\
2004 \\
\end{array}$ & $\begin{array}{l}2005 \\
2006 \\
\end{array}$ & $\begin{array}{l}2007 . \\
2008\end{array}$ & $\begin{array}{l}2009 \\
2010\end{array}$ & Média \\
\hline Direita & $.2,2$ & $.5,7$ & $.7,7$ & $.0,2$ & $-1,5$ & $.12,1$ & $.8,4$ & $.8,5$ & $.11,9$ & 1,7 & 2,2 & $.4,9$ \\
\hline Centro & 7,4 & 10,5 & 18,6 & 6,6 & 6,2 & 17,2 & 10,0 & 13,6 & 16,2 & 10,7 & 9,6 & 11,5 \\
\hline Esquerda & $.7,9$ & $.9,0$ & $-10,3$ & $.6,4$ & $.5,7$ & $.4,9$ & $.1,7$ & $\cdot 5,1$ & $.5,1$ & $.11,0$ & $.9,7$ & $.7,0$ \\
\hline Outros** & 2,7 & 4,1 & $.0,6$ & 0,0 & 1,0 & $.0,2$ & 0,1 & 0,0 & 0,8 & $.1,4$ & $-1,9$ & 0,4 \\
\hline Interblocos & 10,1 & 14,7 & 17,9 & 6,6 & 7,2 & 17,2 & 10,1 & 13,6 & 17,0 & 12,4 & 11,8 & 12,4 \\
\hline
\end{tabular}

Fonte: Elaboração própria, a partir de dados do Senado e da Câmara (2011).

*Cálculo: Índice = (PSenado - PCâmara), em que P corresponde à proporção de cadeiras de cada bloco. A última linha é calculada pela fórmula da volatilidade entre blocos, proposta por Bartoline e Mair (1990) a partir da fórmula da volatilidade total. *Vide nota 9

Para cada biênio, foi calculado o número percentual de cadeiras de cada bloco em cada Casa; depois, foi feita a operação "blocos do Senado" menos "blocos da Câmara", de modo que os sinais negativos indicam blocos menores do Senado. Os dados mostram que, em termos percentuais, os extremos ideológicos foram sistematicamente mais representados pelos deputados, enquanto o centro teve mais peso entre os senadores.

Dadas as características do presidencialismo brasileiro, esse é um perfil interessante para a segunda Casa, pois a vantagem numérica dos parlamentares de centro diminui as chances de formação de uma maioria antigovernista recalcitrante, viabilizando a composição de bases governistas majoritárias. Tendo em vista que a contiguidade ideológica viabiliza a formação de blocos partidários, devido à aproximação das preferências políticas (COPPEDGE, 1998; GARCíA-DIEZ e BARAHONA, 2002; INÁCIO e NUNO, 2005; INÁCIO, 2006), o centro se encontra numa posição vantajosa, devido a sua contiguidade em relação aos outros dois blocos ideológicos. Sendo de centro sem chefiar o governo, os partidos podem compor tanto o bloco de oposição quanto o governista. No entanto, considerados a centralidade do Executivo no sistema brasileiro e o seu controle sobre recursos politicamente cobiçados, os governos têm vantagens frente à oposição em suas tentativas de atrair o centro, seja para um apoio ad hoc, para votar pontos específicos do programa governamental, seja para um apoio mais estável, como membro da coalizão governista. Um exemplo do primeiro caso é o apoio do PSDB às reformas constitucionais no governo Lula, apoio este decisivo à aprovação da reforma da previdência, a despeito de o partido ser um manifesto opositor do PT e o mais forte rival deste nas últimas eleições presidenciais (ANASTASIA e MELO, 2005). O PMDB se enquadra no segundo caso. Além de vizinho ideológico do governo, este partido não

\footnotetext{
${ }^{9}$ Uma discussão sobre consistência ou inconsistência ideológica dos partidos brasileiros está além dos objetivos deste artigo. Assume-se que as distinções ideológicas existem e afetam em grau relevante o perfil dos legisladores, o comportamento parlamentar e as disputas políticas no interior do Congresso Nacional, como sustentam, entre outros, os trabalhos de Melo (2004), Santos e Almeida (2005), Anastasia e Melo (2005), Rodrigues (2002). Aqui, os blocos ideológicos foram definidos conforme Santos e Almeida (2005) e Carreirão (2006). Esquerda: PSTU, PCdoB, PT, PSB, PDT, PPS, PV, PMN; Centro: PMDB, PSDB; Direita: PL, PTB, PRP, PSD, PSL, PPR, PFL/DEM, PSC, PP, PPB, PRONA. Parlamentares sem partido ou de partidos que não puderam ser ideologicamente posicionados (PST, PHS, PTC, PTN, PTdoB, PSDC, PAN) foram incluídos na categoria "outros", conforme consta na Tabela 1.
} 
tem concorrido à presidência da República e, como tal, segundo Miranda (2010), é particularmente propenso a integrar a base parlamentar governista, devido à atração exercida pelos incentivos inerentes à participação no governo ${ }^{10}$.

O fato é que, no geral, a configuração ideológico-partidária do Senado no período analisado mostrou-se favorável à promoção do apoio parlamentar ao Executivo, sugerindo que, uma vez que os projetos de cunho ideológico tenham sobrevivido à Câmara, os acordos tendem a ser mais viáveis entre os senadores.

Até aqui, os dados delineiam uma configuração política mais propícia aos acordos no Senado, se comparado com a Câmara dos Deputados. Isso é compatível com a impressão generalizada de que a Câmara Alta brasileira - como as câmaras altas em geral - é um ambiente onde os debates são, normalmente, mais moderados do que na Câmara Baixa. Vale ressalvar, contudo, que o esforço do presente artigo é, precisamente, o de problematizar essa visão, que beira ao senso comum e ao folclore político, mostrando que a atuação do Senado é mais complexa, assentada num imbricado encadeamento institucional em que as preferências dos senadores são consideradas, se não na própria Casa, em outras etapas ou instâncias do processo decisório.

Para seguir na análise, cabe comparar a composição política das Casas com base nas coalizões de governo, para verificar em que medida elas convergem com o padrão acima mostrado, favorecendo (ou não) os acordos entre o Executivo e os senadores. Tendo em vista que o objetivo do presente artigo é analisar a atuação dos senadores como revisores de propostas do Poder Executivo, e tendo em vista a importância das coalizões na interação do Executivo com o Congresso, é fundamental saber quais os efeitos das estratégias coalizacionais do governo sobre a composição política bicameral.

\section{De Sarney a Lula: efeitos das estratégias de coalizão sobre a representação bicameral}

No Brasil, grande parte dos projetos de lei apreciados pelos parlamentares é apresentada pelo governo ou é de seu interesse. Dados os poderes do Senado como veto point, o aspecto bicameral da base governista se torna uma questão de especial importância. Afinal, em que medida o comportamento dos senadores é afetado pelas características das coalizões de governo? E que características das coalizões são significativas para as interações bicamerais?

Há diversas variáveis relevantes ao estudo dessas questões (GARCÍA-DIEZ e BARAHONA, 2002), três são consideradas aqui: o tamanho das coalizões, suas taxas de heterogeneidade ideológica e o número

\footnotetext{
10 Segundo a autora, ao optar reiteradamente por não pleitear a presidência, os partidos ficam à mercê das benesses do Executivo para se manterem eleitoralmente competitivos para o parlamento. Daí o comportamento das lideranças indicarem maior empenho dessas em coligar-se com o governo, no âmbito parlamentar, esforçando-se para assegurar o apoio do partido às propostas governamentais (MIRANDA, 2009). No caso do PMDB, pode-se deduzir que sua ausência reiterada na disputa da presidência somada a sua contiguidade ideológica tanto à esquerda quanto à direita, torna-o um parceiro previsível dos sucessivos governos, motivo pelo qual seu grande peso no Senado tende a abrir ao Executivo boas possibilidades de negociação. Vale mencionar, ainda, que a heterogeneidade interna desse partido, que a autora define como descentralizado, não o inviabiliza como apoiador parlamentar relevante do Executivo. Miranda (2008; 2009) avalia a disciplina partidária no Congresso, em votações nominais ocorridas de 1991 a 2007, e mostra que as taxas relativas ao PMDB superam, na média, os 80\%. Os dados da autora permitem comparar Câmara e Senado com base nas votações ocorridas no segundo governo de Fernando Henrique Cardoso e nos dois governos Lula (até 2007). A taxa média de disciplina do PMDB no Senado é 82,7 e na Câmara é 83,8. Vale citar, ainda, o trabalho de Batista e Melo (2012), que analisam o comportamento do PMDB em votações nominais na $51^{a}$ e $52^{a}$ Legislaturas, mostrando que seus níveis de disciplina, nas duas casas, são equiparáveis aos do DEM, do PSDB e do PT. Enfim, os dados mostram uma convergência relativamente alta entre senadores e entre deputados, e os patamares percentuais não se diferenciam significativamente entre as casas, a despeito de certa expectativa de que os "figurões" do Senado sejam menos
} obedientes aos partidos. 


\section{ARAÚJO, P. M. Bicameralismo e Poder Executivo no Brasil: revisão de projetos...}

de partidos que elas agregam. Com base nesses parâmetros, importa verificar o perfil dos blocos formados pelos governos para interagir com o Congresso.

Para os propósitos em vista, o tamanho, se majoritário ou não, os graus de heterogeneidade ideológica e o NEP das coalizões (NEPC) são importantes tanto em termos absolutos quanto relativos. A importância absoluta se deve ao fato de que, mantidas as demais variáveis, coalizões amplas e NEPCs reduzidos tendem a resultar em apoios mais consistentes, ao contrário, coalizões pequenas e NEPCs altos tendem a produzir mais dificuldades nas negociações entre o governo e os legisladores (INÁcIO, 2006). A importância relativa decorre do caráter bicameral do Legislativo brasileiro, que faz com que os efeitos da configuração política sobre as negociações na segunda Casa dependam da configuração que ambientou as negociações na primeira, e vice-versa. Se, por exemplo, o NEP de certa coalizão na Câmara de origem é maior que na revisora, é de se esperar que a parte mais difícil das negociações ocorra na origem, já que a constelação de interesses ali presente é mais complexa e pode contemplar (incorporar, antecipar) as demandas da Casa revisora. A mesma lógica se aplica ao "tamanho" e à "heterogeneidade ideológica" da coalizão: ceteris paribus, as discrepâncias intercamerais nos valores de cada variável devem estar positivamente associadas com os graus de conflito entre as Casas.

Os dados do período abordado são apresentados adiante. Começa-se pelo tamanho dos blocos de governo e oposição, mostrado na Tabela 2. Embora a construção formal de maiorias não seja necessária para a interação bem sucedida do governo com o Legislativo (CHEIBUB, PRZEWORSKI E SAIEGH, 2004), no Brasil, desde Sarney, há notório esforço dos presidentes para construir bases de apoio majoritárias ou supermajoritárias.

Tabela 2

Tamanho das coalizões e das oposições

(1989-2010)

\begin{tabular}{|c|c|c|c|c|c|}
\hline \multirow{2}{*}{$\begin{array}{l}\text { Coalizões, por } \\
\text { governo }\end{array}$} & \multicolumn{2}{|c|}{ (\%) bancadas no Senado } & \multicolumn{2}{|c|}{ (\%) bancadas na Câmara } & \multirow[t]{2}{*}{$(a-b)$} \\
\hline & Governo (a) & Outros & Governo (b) & Outros & \\
\hline Sarney & 63,0 & 37,0 & 63,9 & 36,1 & $.0,9$ \\
\hline Collor 1 & 22,2 & 77,8 & 24,2 & 75,8 & $.2,0$ \\
\hline Collor 2 & 30,9 & 69,1 & 32,8 & 67,2 & $-1,9$ \\
\hline Collor 3 & 37,0 & 63,0 & 35,2 & 64,8 & 1,8 \\
\hline Franco 1 & 78,4 & 21,6 & 64,4 & 35,6 & 14 \\
\hline Franco 2 & 69,1 & 30,9 & 46,3 & 53,7 & 22,8 \\
\hline FHC I 1 & 73,5 & 26,5 & 56,3 & 43,7 & 17,2 \\
\hline $\mathrm{FHCl} 2$ & 84,6 & 15,4 & 77,2 & 22,8 & 7,4 \\
\hline $\mathrm{FHC} \mathrm{I} 3$ & 84,0 & 16,0 & 77,6 & 22,4 & 6,4 \\
\hline $\mathrm{FHC} \| 1$ & 82,7 & 17,3 & 73,7 & 26,3 & 9,0 \\
\hline FHC II 2 & 76,5 & 23,5 & 67,6 & 32,4 & 8,9 \\
\hline $\mathrm{FHC} \| \mathrm{I}$ & 44,4 & 55,6 & 35,3 & 64,7 & 9,1 \\
\hline Lula | 1 & 37,0 & 63,0 & 42,5 & 57,5 & $.5,5$ \\
\hline Lula I 2 & 56,2 & 43,8 & 64,7 & 35,3 & $.8,5$ \\
\hline Lula I 3 & 52,5 & 47,5 & 57,7 & 29,2 & $.5,2$ \\
\hline Lula | 4 & 48,1 & 51,9 & 58,3 & 41,5 & $\cdot 10,2$ \\
\hline Lula I 5 & 51,2 & 48,8 & 69,6 & 30,4 & $.18,4$ \\
\hline Lula II 1 & 54,3 & 45,7 & 60,4 & 39,6 & $\cdot 6,1$ \\
\hline Lula II 2 & 60,5 & 39,5 & 65,1 & 34,9 & $.4,6$ \\
\hline Lula II 3 & 65,4 & 34,6 & 67,6 & 32,4 & $.2,2$ \\
\hline Lula II 4 & 63,0 & 37,0 & 67,6 & 32,4 & $-4,6$ \\
\hline Média & 58,8 & 41,2 & 57,8 & 41,9 & 7,9 \\
\hline
\end{tabular}

Fonte: Elaboração própria. Os dados sobre a Câmara foram organizados a partir de Inácio (2006), Figueiredo (2006)

e Pasquarelli (2011). Os dados sobre o tamanho das coalizões no Senado resultam de pesquisa própria, a partir de dados disponíveis no site da Casa (2011). 
A Tabela 2 apresenta os contingentes legislativos dos blocos parlamentares e aponta o efeito das estratégias de coalizões sobre a configuração bicameral da base governista e da oposição. As diferenças (coluna à direita), se consideradas sem o sinal, equivalem a taxas de divergência bicameral entre blocos do governo e da oposição e indicam que a formação de coalizões diminui em grau considerável a discrepância na representação bicameral. Os valores observados no período perfazem uma média de 7,9, sendo, portanto, sensivelmente menores que os índices de divergência total (de 22,3), baseados nas bancadas partidárias, ou de divergência interblocos $(12,6)$, baseadas nos segmentos ideológicos (vide Tabela 1 ).

A literatura é pródiga em estudos que mostram um alto grau de disciplina no comportamento de parlamentares governistas em votações nominais de interesse do Executivo. Sobre a Câmara dos Deputados, Inácio (2006) informa que, para o período 1990-2004, “o Índice de Rice médio das coalizões governativas foi igual a 79, indicando um patamar elevado de unidade do comportamento da coalizão no plenário" (INÁCIO, 2006, p. 139). Sobre o Senado, estudo de Simão Branco (2008) revela alto nível de adesão da bancada governista senatorial às orientações do governo. $O$ autor analisa as votações nominais ocorridas no processo de negociação das dívidas dos bancos estaduais e na criação do fundo social de emergência, com suas sucessivas renovações, constatando que os índices de apoio dos senadores ao governo são ainda maiores que na Câmara (SIMÃo BRANCO, 2008, p. 322.323). Importa frisar que isso ocorreu apesar de as votações analisadas se referirem a questões polêmicas do pacto federativo e terem, portanto, se dado em meio ao conflito de interesses entre o governo federal e os governos estaduais e municipais. Correlativamente, o autor mostra que os votos contrários à posição do governo saíram, na sua quase totalidade, dos partidos não membros da coalizão. Esses dados são reforçados por Miranda (2009), Neiva (2011) e Melo e Batista (2012), que comparando o comportamento de senadores e deputados em votações nominais constatam que, nas duas Casas, os graus de disciplina são altos, tanto em partidos do governo quanto da oposição.

A despeito das variações nas taxas de disciplina seja entre partidos seja entre governos, os estudos supracitados apontam para a importância da clivagem coalizão-oposição como fator condicionante das relações entre Senado e Câmara. Se o pertencimento dos partidos à base governista induz ao comportamento cooperativo de seus parlamentares em relação ao Executivo e, inversamente, a filiação à oposição aumenta as probabilidades de um comportamento obstrutivo, a formação de coalizões se torna um meio estratégico de o governo mitigar os efeitos dos mecanismos de incongruência do bicameralismo. Assim, a despeito de a redução da divergência bicameral através da formação de coalizões ser um artifício político que encobre as discrepâncias partidárias intercamerais, suas consequências sobre a relação entre as Câmaras são relevantes e devem ser consideradas.

Com isso, a variável "tamanho da base governista" se coloca no centro problema. Com as altas taxas de apoio dos parlamentares da coalizão, por um lado, e com as dificuldades de arregimentar apoio dos membros de partidos não coligados, por outro, a base (minimamente ou super) majoritária se torna atrativa como sustentáculo para a interação Executivo-Legislativo. Portanto, tendo em vista o poder de veto da câmara revisora no Brasil, os melhores parceiros do governo são aqueles que, coalizando-se, asseguram nas duas Casas o apoio necessário à aprovação das medidas. 


\section{ARAÚJO, P. M. Bicameralismo e Poder Executivo no Brasil: revisão de projetos...}

De fato, os dados mostram que a formação de blocos bicameralmente majoritários tem sido a opção mais comum, embora, em boa parte do período em foco, as estratégias coalizacionais tenham produzido bancadas maiores na Câmara que no Senado. Essa defasagem se deu, por pequenas diferenças pró-Câmara, nos governos Sarney e Collor e, por diferenças maiores, ao longo de todo o período Lula. A parceria de Lula com pequenos partidos, sobretudo à esquerda do espectro ideológico, foi decisiva para a configuração bicameral de sua base de apoio senatorial. Conforme lembrado anteriormente, eleições majoritárias como as do Senado inibem a ascensão dos pequenos partidos, motivo porque a base lulista foi sempre maior entre os deputados - sendo, mesmo assim, quase sempre majoritária também no Senado. O Gráfico 3 mostra a dispersão das coalizões de governo do período, de acordo com a combinação de seu status majoritário ou minoritário no Senado e na Câmara dos Deputados:

\section{Gráfico 3}

Dispersão das coalizões, conforme o tamanho percentual de suas bancadas no Senado e na Câmara

(1989-2010)

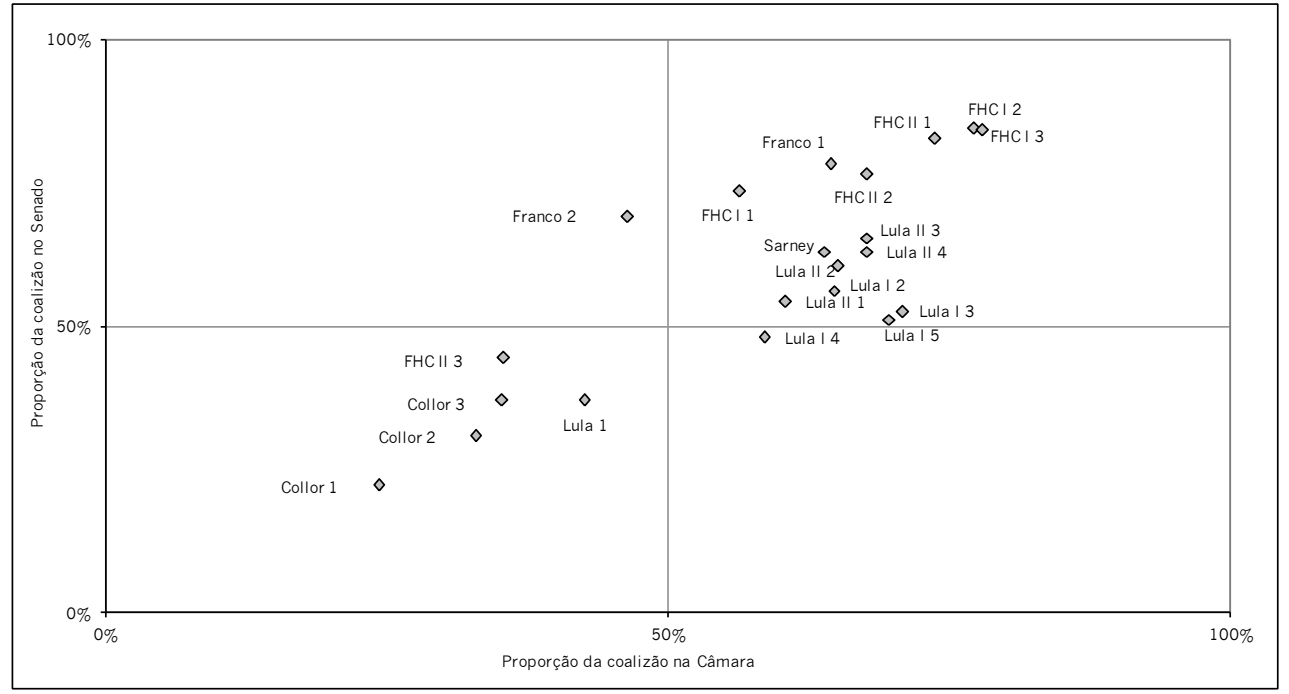

Fonte: Elaboração própria, a partir de dados do Senado e da Câmara (2011).

A despeito de as regras eleitorais terem efeitos diferenciados sobre o peso dos partidos numa e noutra Casa - com impactos sensíveis nas taxas de divergência bicameral ·, as estratégias de coalizão adotadas pelos presidentes resultaram em patamares de apoio convergentes, isto é, bicameralmente equivalentes em termos do status majoritário ou minoritário das coalizões. O índice de correlação de Pearson entre os tamanhos das bases aliadas na Câmara e no Senado é 0,805 (sig. 0,000), indicando que, no período considerado, as parcerias formadas impactaram fortemente, na mesma direção, a força política das bases governistas.

Os governos Itamar 2 e Lula I 4 foram os únicos com coalizões divergentes, aquele majoritário no Senado e minoritário na Câmara, este o inverso. Sendo 14 em 21, as coalizões bicameralmente majoritárias despontam como as preferidas dos presidentes. Lula iniciou seu governo com uma base bicameralmente minoritária, mas optou por ampliá-la de modo substancial, cedendo pastas ministeriais 
ao PMDB. Com seu movimento em direção à direita, rearranjos aconteceram na sua coalizão - saíram parceiros como o PPS, PV e PTB e entrou o PP - colocando a base lulista, no Senado, num ponto de indefinição entre ser maioria ou minoria. Fernando Henrique, nos dois mandatos, optou por ter maioria nas duas Casas para interagir com o Congresso. Apenas no final do segundo mandato teve que lidar com apoio legislativo minoritário, em função da evasão decorrente das articulações voltadas para as eleições nacionais e estaduais que se avizinhavam. Fernando Collor foi o único presidente que se manteve bicameralmente minoritário enquanto durou o mandato. Após a crise que se instaurou em seu governo e afetou profundamente sua relação com o Congresso, Collor fez duas tentativas de alargar suas bases nas duas Casas, mas a gravidade dos conflitos, que levaram ao impeachment, não Ihe permitiu estender sua coalizão o suficiente.

Neste ponto, cabe abordar duas outras variáveis tratadas na literatura como associadas à força dos blocos parlamentares: o número de partidos que os compõem e o espaço que ocupam no espectro ideológico (García-diez e Barahona, 2002; InÁCIO e NUNO, 2005; InÁCIO, 2006). Argumenta-se que o número de partidos está positivamente relacionado com as dificuldades de organização da ação coletiva, de forma que quanto mais partidos precisem ser coordenados maiores as chances de deserções e de cisões no bloco partidário. No entanto, esse problema pode ser mitigado ou acentuado conforme a distribuição dos partidos no espectro ideológico.

Presume-se que o posicionamento das legendas no eixo esquerda-direita é um indicador das preferências contidas na coalizão. Quanto maior a abrangência ideológica desta, mais heterogêneos os interesses que ela agrega e, por consequência, maiores as chances de irrupção de conflitos internos. Assim, nos termos dos autores supracitados, coalizões muito fragmentadas e heterogêneas são mais vulneráveis - e, portanto, politicamente mais fracas - que as pouco fragmentadas e homogêneas. Nas interações bicamerais, as primeiras terão mais dificuldades para garantir que os acordos na Casa de origem sejam respeitados na Casa revisora. Isso posto, para avaliar os cenários das interações do Senado com a Câmara em função da agenda do Executivo, cabe observar a estrutura dos blocos governistas que atuaram no período.

A Tabela 3 mostra o número efetivo de partidos e a amplitude ideológica das coalizões. Esta última variável foi definida conforme classificação de Coppedge (1998), utilizada por Inácio (2006). Como nestes estudos, aqui foram atribuídos valores às posições do espectro ideológico - esquerda, centro-esquerda, centro, centro-direita e direita ${ }^{11}$. sendo que a diferença entre os partidos mais distantes entre si indica a abrangência ideológica da coalizão:

\footnotetext{
${ }^{11}$ O posicionamento ideológico foi feito conforme Santos e Almeida (2005) e Carreirão (2006). A pontuação seguiu a seguinte norma: direita $=5$; centro-direita $=4 ;$ centro $=3$; centro-esquerda $=2$ e esquerda $=1$.
} 
ARAÚJO, P. M. Bicameralismo e Poder Executivo no Brasil: revisão de projetos...

Tabela 3

Legendas, partidos efetivos e abrangência ideológica das coalizões entre 1989 e 2010

\begin{tabular}{|c|c|c|c|c|c|}
\hline \multirow[b]{2}{*}{ Ministérios } & \multicolumn{2}{|c|}{ Senado } & \multicolumn{2}{|c|}{ Câmara } & \multirow{2}{*}{$\begin{array}{c}\text { Diferença } \\
(a-b)\end{array}$} \\
\hline & Distância ideológica & $\operatorname{NEPC}(a)$ & Distância ideológica & $\operatorname{NEPC~(b)~}$ & \\
\hline Sarney & 2 & 1,6 & 2 & 1,8 & $.0,2$ \\
\hline Collor 1 & 0 & 1,3 & 0 & 1,5 & $.0,2$ \\
\hline Collor 2 & 0 & 1,8 & 0 & 2,7 & $.0,9$ \\
\hline Collor 3 & 1 & 2,4 & 1 & 3,1 & $.0,7$ \\
\hline Franco 1 & 3 & 3,7 & 3 & 4,4 & $.0,7$ \\
\hline Franco 2 & 2 & 3,1 & 2 & 2,7 & 0,4 \\
\hline FHC I 1 & 2 & 3,2 & 2 & 3,5 & $.0,3$ \\
\hline $\mathrm{FHC} \mid 2$ & 2 & 3,7 & 2 & 4,5 & $.0,8$ \\
\hline $\mathrm{FHC} \mid 3$ & 2 & 3,6 & 2 & 4,6 & $\cdot 1,0$ \\
\hline FHC II 1 & 2 & 3,3 & 2 & 4,4 & $\cdot 1,1$ \\
\hline FHC II 2 & 2 & 3,1 & 2 & 3,8 & $.0,7$ \\
\hline $\mathrm{FHC} \| \mathrm{II}$ & 0 & 2,0 & 0 & 2,0 & 0,0 \\
\hline Lula I 1 & 3 & 3,8 & 3 & 4,6 & $.0,8$ \\
\hline Lula | 2 & 3 & 2,9 & 3 & 5,5 & $\cdot 2,6$ \\
\hline Lula | 3 & 3 & 2,8 & 3 & 5,5 & $.2,7$ \\
\hline \begin{tabular}{|l|l|} 
Lula & 4
\end{tabular} & 3 & 2,9 & 3 & 5,0 & $-2,1$ \\
\hline Lula | 5 & 4 & 2,9 & 4 & 5,3 & $.2,4$ \\
\hline Lula II 1 & 4 & 3,4 & 4 & 5,0 & $\cdot 1,6$ \\
\hline Lula II 2 & 4 & 4,1 & 4 & 5,6 & $\cdot 1,5$ \\
\hline Lula II 3 & 4 & 4,4 & 4 & 6,0 & $\cdot 1,6$ \\
\hline Lula II 4 & 4 & 5,0 & 4 & 6,0 & $\cdot 1,0$ \\
\hline
\end{tabular}

Fonte: Elaboração própria. Os dados sobre a Câmara foram organizados a partir de dados sobre as coalizões apresentados em Inácio (2006), Figueiredo (2006) e Pasquarelli (2011). Os dados sobre o Senado resultam de pesquisa própria, a partir de dados disponíveis no site da Casa (2011).

Seja no número efetivo de partidos nas coalizões (NEPC), seja na amplitude ideológica da coalizão, a Tabela 3 mostra que houve nas duas Casas considerável variação longitudinal nas bases legislativas construídas pelos presidentes que se sucederam desde Sarney. Isso indica que as negociações entre os parlamentares e o Executivo se assentaram, ao longo do período, em diferentes estruturas de preferência e, supostamente, produziram diferentes padrões de negociações internas e de interação das instâncias decisórias em foco - Senado, Câmara e Executivo. Por hipótese, quanto maiores - NEPC e a abrangência ideológica das coalizões na Casa revisora, mais complexas as negociações e maior a probabilidade de que restem (ou surjam) arestas a serem aparadas na etapa de revisão.

O Gráfico 4 apresenta a evolução da incongruência bicameral interna à base governista e ajuda a dimensionar melhor o problema. Considerada a base do governo como uma totalidade (100\%), a incongruência intracoalizão foi calculada a partir da fórmula da volatilidade partidária, pelas razões antes apresentadas. Na média, a taxa de divergência bicameral nas coalizões do período foi baixa, mas não desprezível: 14,5 numa escala de 0 a 100. A variação observada ao longo do período denota diferentes graus de (des)harmonia na composição partidária dos blocos de senadores e deputados que apoiaram o governo. Uma parte de tal variação certamente tem relação com a incongruência nas regras eleitorais; a outra decorre do formato das coalizões, resultante das estratégias presidenciais. Sobre este último ponto, a despeito do pequeno número de casos para um teste de correlação consistente, é razoável aceitar os coeficientes de Pearson como indicador da associação positiva entre os graus de 
incongruência e o NEP da coalizão $(R=0,740 \text {, sig. } 000)^{12}$. Se correta, tal associação significa que quanto mais partidos nas coalizões mais incongruentes elas tenderão a ser. Isso deve criar contextos decisórios mais complexos e, por consequência, mais chances para o dissenso entre as duas Câmaras:

\section{Gráfico 4}

\section{Evolução da incongruência bicameral intracoalizão, entre}

1989 e 2010

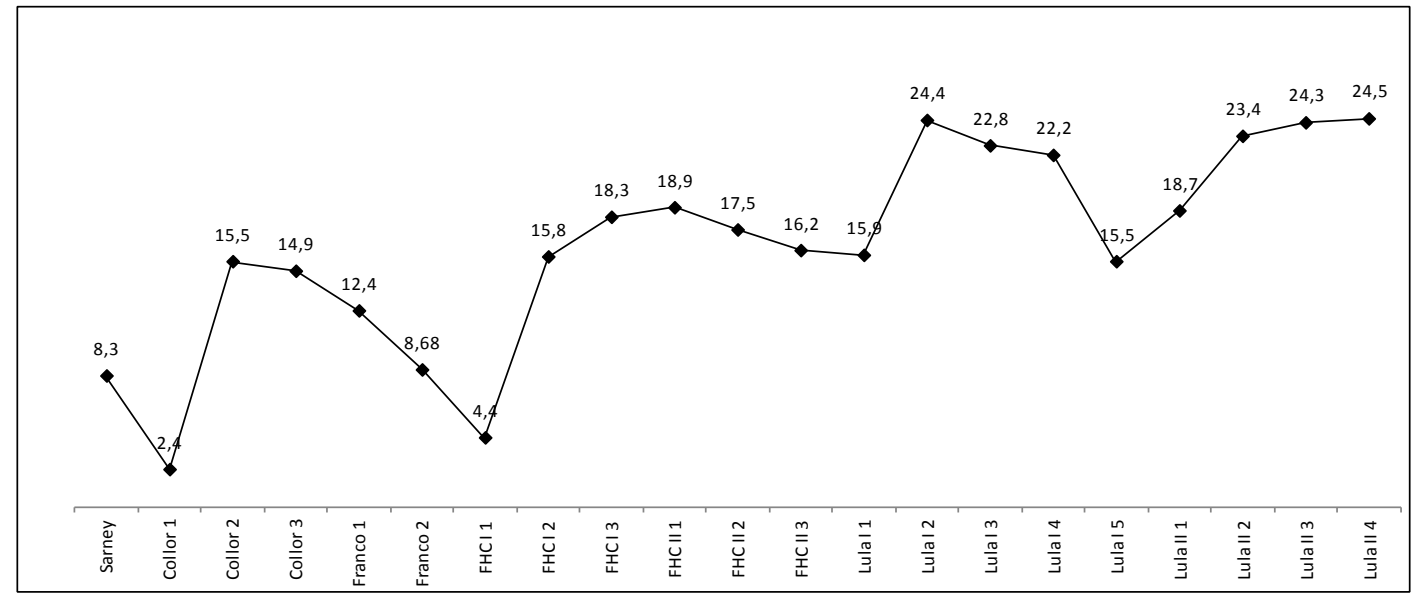

Fonte: Elaboração própria, com base em dados disponíveis nos sites do Senado e da Câmara (2011).

Não obstante a complexidade das negociações, decorrente da estrutura da representação bicameral, uma leitura combinada dos dados mostrados até aqui indica que, com os resultados eleitorais, as estratégias adotadas para coalizões resultaram num cenário mais complexo para as negociações dos governos com os deputados do que com os senadores - não se quer dizer, com isso, que as negociações com os senadores sejam simples, mas que as configurações político-partidárias na Câmara tendem a suscitar mais conflitos, alguns dos quais, ao serem sanados, provavelmente antecipam, e resolvem, conflitos que eclodiriam no Senado.

Tendo em vista que o Senado é a casa revisora de todas as propostas que não as suas próprias, a evolução dos cenários políticos ocorrida no período sugere que as negociações estabelecidas na Câmara puderam reduzir o potencial de obstrução do processo revisor. Supondo-se, com base em Tsebelis e Money (1997), que os interessados na aprovação das leis procuram abreviar ao máximo sua tramitação, a maior abrangência da representação na Câmara pode servir de base para se captar, ainda entre os deputados, os possíveis conflitos de base partidária a serem enfrentados no Senado. Com isso, algumas soluções podem ser antecipadas para evitar desgastes e atrasos desnecessários entre os senadores.

\section{Configuração política e interação bicameral: as bases da atuação do Senado}

Tanto em relação à composição das legislaturas (em termos de biênios) quanto no tocante às coalizões, a estrutura da representação bicameral delineada na seção anterior lança luz à interpretação

\footnotetext{
12 Considerou-se a média: (NEPC Câmara + NEPC Senado)/2.
} 


\section{ARAÚJO, P. M. Bicameralismo e Poder Executivo no Brasil: revisão de projetos...}

dos cenários políticos constituídos pelo Senado, esclarece aspectos do seu funcionamento e fundamenta algumas expectativas em relação às interações bicamerais voltadas para a deliberação de projetos.

Um primeiro ponto a ser destacado é que os indicadores apresentados até aqui reforçaram a ideia de que o Senado, se comparado à Câmara, é uma arena mais propícia ao fluxo decisório, especialmente como casa revisora. Em parte devido às eleições majoritárias, o Senado é ocupado por um número efetivo menor (e menos oscilante) de partidos. Nesse aspecto, os senadores enfrentam menos problemas para organizar maiorias e fechar acordos. Além disso, a comparação das Casas, baseada no peso dos blocos de esquerda, centro e direita, mostrou que no Senado os partidos de centro têm bancadas percentualmente maiores que na Câmara. Esta, ao contrário, abre mais espaços para os extremos ideológicos e é, portanto, mais propícia a polarizações e entraves políticos.

Se avaliadas especificamente as condições de interação Executivo-Legislativo, o ponto a destacar é que as bases governistas no Senado assumiram um perfil menos fragmentado e menos heterogêneo se comparadas àquelas na Câmara, apresentando uma composição mais atraente para o governo: um número menor de partidos e abrangência ideológica nunca maior do que as da Primeira Casa. Também nesse aspecto se conclui que as bases políticas e institucionais do bicameralismo brasileiro tornam o Senado mais favorável à tomada de decisões - e não à obstrução política, como preveem alguns analistas (BACKES, 1999; 2008; STEPAN, 1999; MAINWARING, 2001).

Destacou-se ainda, como elemento positivo para o sucesso legislativo do Executivo entre os revisores, a alta correlação entre o status da coalizão na Câmara e no Senado, de modo que, sendo majoritária naquela Casa, há grande probabilidade de que o seja também nesta. Entre as 21 coalizões contabilizadas no período, 14 foram bicameralmente majoritárias, sendo que 9 lograram um percentual mais amplo de cadeiras na segunda câmara. Dadas as regras partidárias de composição das instâncias decisórias intraparlamentares (FIGUEIREDO e LIMONGI, 1999; SANTOS, 2003; ARAúJO, 2009), o tamanho das bancadas impacta diretamente o grau de controle da coalizão sobre os ativos institucionais no âmbito parlamentar.

Segundo definição de Inácio, ativos institucionais são "direitos e recursos legislativos e executivos", que definem "a capacidade diferencial [do governo e das oposições] para influenciar a produção de políticas” (INÁCIO, 2006, p.30). Fundamentalmente, os ativos institucionais correspondem ao controle de cargos parlamentares relevantes e seus efeitos na capacidade de seus detentores para controlar o processo decisório interno. Nestes termos, o grau de domínio exercido pela parte senatorial da coalizão sobre os postos-chave da estrutura parlamentar reflete sua força política para conformar a legislação a seu gosto, tornando mais previsíveis os resultados dos processos deliberativos. Os dados apresentados nas Tabelas 4 e 5 permitem analisar essa questão com base em dados empíricos. 
OPINIÃO PÚBLICA, Campinas, vol. 20, no 1, abril, 2014, p. 67-95

Tabela 4

Distribuição, por partido, dos cargos mais importantes na Câmara dos Deputados e no Senado Federal (1989-2010)

\begin{tabular}{|c|c|c|c|c|c|c|c|c|}
\hline \multirow{2}{*}{ Biênios } & \multicolumn{2}{|c|}{$\begin{array}{l}\text { Presidente } \\
\text { da CCJ }\end{array}$} & \multicolumn{2}{|c|}{$\begin{array}{l}\text { Presidente } \\
\text { da CAE/CFT }\end{array}$} & \multicolumn{2}{|c|}{$\begin{array}{c}\text { Presidente } \\
\text { da Mesa Diretora }\end{array}$} & \multicolumn{2}{|c|}{$\begin{array}{c}1^{\circ} \text { secretário } \\
\text { da Mesa Diretora }\end{array}$} \\
\hline & Senado & Câmara & Senado & Câmara & Senado & Câmara & Senado & Câmara \\
\hline $1989 \cdot 1990$ & PMDB & PMDB & PMDB & PFL & PMDB & PMDB & PMDB & PMDB \\
\hline 1991-1992 & PMDB & PMDB & PMDB & PFL & PMDB & PMDB & PSDB & PFL \\
\hline 1993.1994 & PMDB & PMDB & PFL & PFL & PMDB & PFL & PFL & PMDB \\
\hline $1995 \cdot 1996$ & PMDB & PFL & PMDB & PMDB & PMDB & PMDB & PFL & PSDB \\
\hline 1997.1998 & PFL & PMDB & PSDB & PSDB & PFL & PMDB & PMDB & PSDB \\
\hline 1999.2000 & PFL & PFL & PMDB & PSDB & PFL & PMDB & PMDB & PSDB \\
\hline $2001 \cdot 2002$ & PFL & PSDB & PMDB & PMDB & PMDB & PSDB & PTB & PPB \\
\hline $2003 \cdot 2004$ & PFL & PT & PMDB & PL & PMDB & PT & PFL & PMDB \\
\hline $2005 \cdot 2006$ & DEM & PT & PMDB & PMDB & PMDB & PP/PCdoB & DEM & PMDB \\
\hline $2007 \cdot 2008$ & DEM & PMDB & PT & PT & PMDB & PT & DEM & PMDB \\
\hline $2009 \cdot 2010$ & DEM & PMDB & PMDB & PT & PMDB & PT & DEM & PSDB \\
\hline
\end{tabular}

Fonte: Elaboração própria, a partir de documentos e dos sites da Câmara e do Senado (2011).

A Tabela 4 apresenta, por biênio, a distribuição partidária dos cargos considerados mais importantes nas duas Casas: as presidências da CCJ e da CAE/CFT ${ }^{13}$, bem como a presidência e a primeira secretaria da Mesa Diretora. Em negrito, estão as legendas que pertenceram à coalizão governista durante a metade ou mais do biênio.

A relação entre o tamanho da base e o grau de controle sobre os cargos é evidente. Nota-se que a perda de cargos importantes no Senado se deu nos governos Collor (1990/92) e Lula (2003/2010), coincidindo totalmente com as ocasiões em que o Executivo tinha bases minoritárias ou maiorias apertadas (mais que na Câmara) entre os senadores. O fato é que o Executivo enfrentou mais dificuldades para controlar os postos-chave na organização senatorial quando sua base no Senado era minoritária tanto em termos absolutos (exclusivamente na Casa) quanto em termos relativos (no Senado frente à Câmara). Isso mostra que, na formação das coalizões, os governos não podem menosprezar a dimensão bicameral dos acordos, isto é, devem levar em conta a configuração partidária do Senado, a menos que queiram encarar perda de influência nas decisões senatoriais.

Não obstante esses biênios críticos, a análise agregada da distribuição dos cargos parlamentares mais relevantes mostra que, no Senado, tendencialmente, a base governista atua em situação mais confortável, em posição igual ou melhor que na Câmara.

No caso do período Lula - cuja coalizão ficou o maior tempo em defasagem no Senado ·, cabem considerações. A perda da presidência da CCJ entre os senadores, embora impactante, não é tão decisiva quanto seria na Câmara, onde a base lulista a controlou todo o tempo. No Senado, a avaliação da admissibilidade dos projetos por seus aspectos constitucionais-legais não é monopólio da CCJ;

${ }^{13}$ CCJ, Comissão de Constituição e Justiça e Cidadania, no Senado e na Câmara dos Deputados; CAE, Comissão de Assuntos Econômicos, no Senado; CFT, Comissão de Finanças e Tributação, na Câmara. 


\section{ARAÚJO, P. M. Bicameralismo e Poder Executivo no Brasil: revisão de projetos...}

qualquer comissão cumpre essa função para os projetos que Ihe são encaminhados ${ }^{14}$, tal que a CCJ, como qualquer outra comissão na Casa, concentra sua atuação prioritariamente na avaliação do mérito das questões.

No tocante aos cargos da Mesa, a desvantagem relativa da base governista no Senado se deve unicamente à perda do posto de primeiro secretário para a oposição. Sendo assim, pode-se dizer que a situação do governo entre os senadores não foi crítica: primeiro, porque o cargo mais importante, o de presidente, foi igualmente dominado pelo governo nas duas Casas; segundo, porque a Mesa Diretora do Senado, enquanto colegiado, é praticamente destituída de prerrogativas atinentes ao processo legislativo. Ao contrário do que ocorre na Câmara, onde a Mesa toma decisões colegiadas que afetam a agenda política do Congresso, as atribuições da Mesa no Senado são, em geral, administrativas. Inversamente, enquanto o presidente da Câmara divide poder com a Mesa, o Colégio de Líderes e os presidentes de comissões, no Senado, a presidência tem amplo poder formal para conduzir a agenda da Casa de modo discricionário (RICCI, 2008; ARAújo, 2009; MIRANDA, 2010), inclusive no tocante à escolha das comissões para onde, e quando, encaminhar os projetos. $O$ fato é que ter no Senado um presidente aliado do governo deve ter ajudado o presidente Lula a contornar a oposição na CCJ - que, como dito, não é passagem obrigatória dos projetos, como na Câmara.

Enfim, sem desmerecer a importância da CCJ e do cargo de primeiro secretário - este controla cargos e recursos administrativos cobiçados pelos parlamentares -, é plausível interpretar a "abnegação" da coalizão no Senado como estratégica e vantajosa naquele contexto. Ocupar a presidência da CCJ e postos na Mesa que não o de presidente, tem um impacto político menor entre os senadores do que entre os deputados. Se, no processo de distribuição dos cargos, os governistas precisaram ceder postos influentes aos não aliados, foi melhor escolha fazê-lo no Senado - onde os cargos perdidos tem menos influência política ·, uma vez que mantiveram a presidência da Casa sob o controle da coalizão.

Considerada na totalidade, a distribuição partidária das presidências no sistema de comissões reforça a ideia de que, em tendência, o Senado oferece horizontes favoráveis ao sucesso legislativo do governo. Os dados da Tabela 5 confirmam o efeito da política de coalizões no controle dos ativos institucionais, pois se nota que os períodos críticos enfrentados pelo Executivo no controle do sistema comissional do Senado coincidiram, novamente, com o tamanho (absoluta ou relativamente) pequeno da coalizão na Casa:

\footnotetext{
${ }^{14}$ As comissões podem, caso achem necessário, pedir parecer da CCJ em relação aos aspectos jurídicos de um projeto em particular, mas isso não é obrigatório.
} 
OPINIÃO PÚBLICA, Campinas, vol. 20, no 1, abril, 2014, p. 67-95

Tabela 5

Percentual de comissões presididas por membros da coalizão

(1989 a 2007)

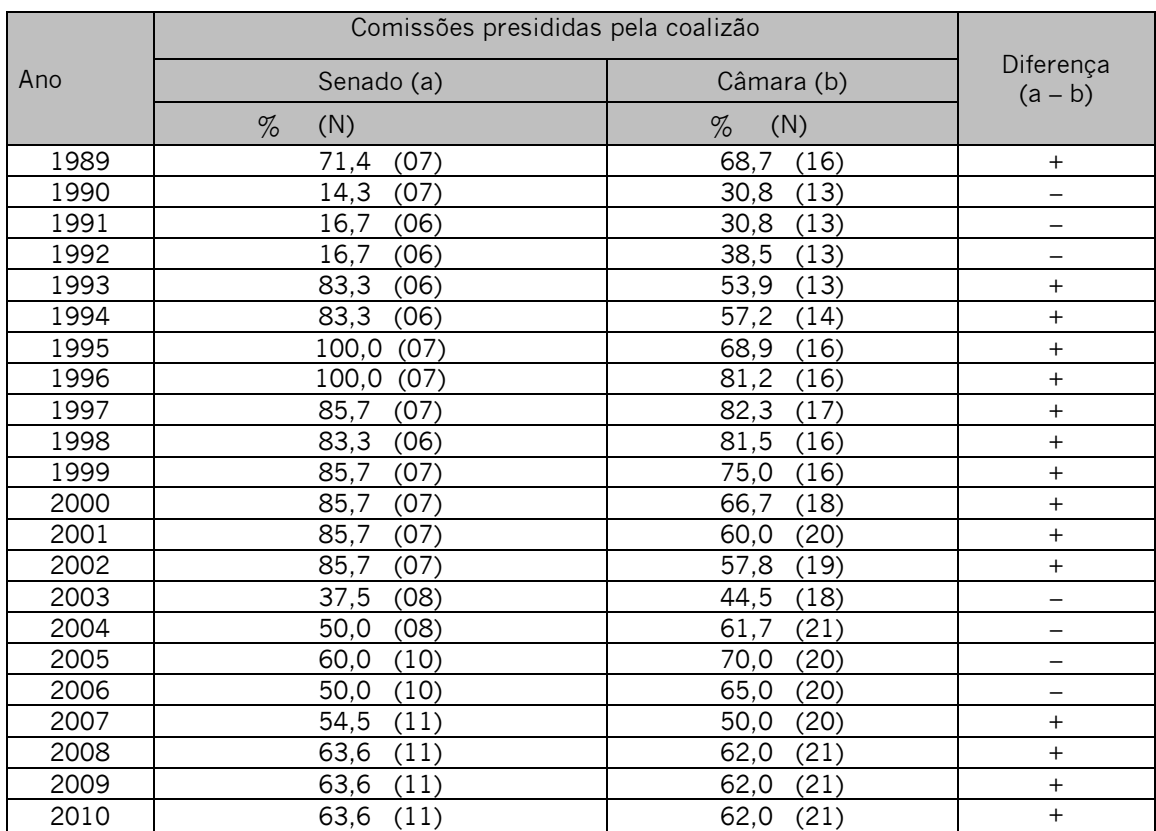

Fonte: Elaboração própria, a partir de dados obtidos em publicações e nos sites do Senado e da Câmara (2011).

Os dados sobre a Câmara, relativos ao período 1990-2004, foram extraídos de Inácio (2006).

No agregado, percebe-se que a política de coalizões do governo produziu efeitos mais vantajosos no Senado. Em 15 dos 22 anos considerados, o percentual de controle do governo sobre as vagas mais importantes no sistema comissional foi maior entre os senadores, mostrando a importância das coalizões majoritárias como forma de controle de instâncias parlamentares relevantes por parte do partido do governo ou seus aliados.

Conclui-se que, ao longo do período considerado, a composição política do Senado propiciou horizontes tendencialmente favoráveis aos governos. Ademais, vale lembrar que, tratando-se de projetos do Executivo, os senadores atuaram sempre como revisores - cujos interesses podem, por isso mesmo, ser atendidos por antecipação. Sendo assim, é possível compreender a imagem da Casa como instância decisória "moderada" e "ratificadora" dos acordos estabelecidos externamente. Parece claro que o comportamento do Senado, tendencialmente convergente com as demandas do Executivo, resulta dos incentivos gerados por sua configuração político-partidária, que, por sua vez, decorre da modelagem institucional do sistema decisório e das estratégias levadas a cabo pelos governos que se sucederam, posteriormente à Constituição de 1988.

Sem dúvida, essas conclusões são pertinentes como diagnósticos gerais. Por um lado, apreende-se a estrutura de incentivos políticos e institucionais que mitigam os efeitos obstrutivos da segunda Câmara no bicameralismo brasileiro, prenunciados por autores como Backes (1999; 2008), Stepan (1999) e Mainwaring (1997, 2001); por outro, as oscilações na configuração político-partidária da representação bicameral indicam maior ou menor dificuldade para a formação de maiorias e 


\section{ARAÚJO, P. M. Bicameralismo e Poder Executivo no Brasil: revisão de projetos...}

possibilitam dissensos ocasionais entre as duas Câmaras, dissensos estes que não são devidamente considerados nos estudos de autores como Figueiredo e Limongi (1999).

Neste estágio, porém, a questão é saber se as hipóteses se confirmam, ou seja, se existe, de fato, correlação significativa entre as variações longitudinais observadas na configuração política do Senado e as variações no padrão de cooperação desta Casa em relação às decisões tomadas na Câmara. Colocado em outros termos: é correto afirmar que a manifestação contundente ${ }^{15}$ da simetria é condicionada pela composição partidária do Senado e pela incongruência da representação bicameral? Na próxima e última parte do artigo, serão testadas algumas hipóteses sobre essa questão.

Como indicador dos graus de cooperação ou conflito entre as duas Casas, será considerado o emendamento, como variável dependente binária. Por suposto, qualquer que seja a emenda ${ }^{16}$, sua ocorrência reflete, em alguma medida, a manifestação dos interesses político-partidários no plano das relações bicamerais. Lembrando Tsebelis e Money (1997), cabe ressaltar que as emendas podem, por um lado, indicar tentativas de aperfeiçoamento (das propostas) resultantes da "função de eficiência" do bicameralismo; por outro, as emendas podem expressar o exercício da "função política" do processo bicameral, ou seja, a tentativa (antecipada ou não) dos legisladores para tornar o projeto mais representativo das forças parlamentares em cena. Se "eficiente", o emendamento é consensual por indicar um movimento em direção ao ponto ótimo de Pareto, onde ao menos um interesse é mais bem atendido e nenhum outro é prejudicado ${ }^{17}$; se "político", o emendamento envolve perdas e ganhos, sendo, portanto, sugestivo de conflito entre as Casas.

Numa análise de dados agregados, como é o caso, não é possível saber quando uma emenda é "eficiente", melhorando o projeto sem ferir interesses, ou quando é "política", expressando jogos de soma zero. Mas essa limitação não inviabiliza a hipótese de que a divergência bicameral é um fator positivamente associado ao emendamento, pois, logicamente, as discrepâncias na representação entre uma Casa e outra ampliam tanto a diversidade dos interesses políticos a serem acomodados no processo legislativo quanto a variedade dos pontos de vista que podem subsidiar o aperfeiçoamento das propostas.

\section{Variáveis decisivas na cooperação condicional do Senado nas decisões bicamerais}

Tendo por base os argumentos e dados mobilizados até aqui, importa especificar as hipóteses a serem testadas e a metodologia empregada. Controlados o tipo, a natureza e o conteúdo das propostas, bem como a autoria dos projetos por governo, o regime e o tempo de tramitação, espera-se que a propensão ao emendamento por parte do Senado esteja positivamente relacionada à complexidade da representação bicameral. Para o teste de hipóteses, o grau de complexidade da representação política no Senado é mensurado a partir de características das coalizões de governo.

\footnotetext{
15 Em termos metodológicos, a forma mais simples de testar os efeitos da simetria nas relações bicamerais é por meio das estratégias reativas da casa revisora frente às decisões tomadas na casa de origem. Se aquela concorda com esta, não é possível saber, numa análise de dados agregados, se houve convergência de interesses ou mera subserviência de uma casa à outra; porém, se os revisores discordam dos iniciadores - e se impõem através de emendas, por exemplo - é correto interpretar o fato como manifestação estratégica do poder de veto da casa revisora. Por esse motivo, optou-se por considerar, como indicador efetivo da simetria, as escolhas contundentes do Senado, especificamente aquelas que se expressam no emendamento.

${ }^{16}$ Entendida como alteração em sentido lato: emenda ou substitutivo.

${ }^{17}$ Nestes termos, as emendas de redação seriam exemplos ideais de emendas eficientes, pois aprimoram os projetos sem gerar conflitos políticos, tanto que nem implicam a volta dos projetos à casa de origem, como se dá quando ocorrem emendas de mérito. No entanto, por serem de menor relevância política, as emendas de redação não são consideradas neste artigo.
} 
As coalizões têm seu início e fim definidos pelas articulações entre Executivo e Legislativo na composição dos gabinetes presidenciais; a duração das coalizões depende das eleições legislativas, da estabilidade dos Ministérios e dos mandatos do presidente da República. As coalizões são marcos temporais claros e bem delimitados para os arranjos partidários que condicionam o funcionamento parlamentar.

Pelos parâmetros adotados, apenas parte do banco de dados será usado no teste das hipóteses. Para avaliar os efeitos da estrutura das coalizões na interação bicameral, foi preciso selecionar apenas os projetos que tiveram tramitação completa no Senado durante uma mesma coalizão. Por isso, serão utilizadas 605 das $827(73,3 \%)$ propostas do governo apreciadas pelos senadores no período. Esta produção se compõe de projetos de lei ordinária (560), de lei complementar (29) e propostas de emenda constitucional (16). A análise do emendamento levou em conta apenas os projetos aprovados em votação final no Senado, porque não cabe considerar os projetos em tramitação e os projetos rejeitados em votação final, que seguiram para o arquivo com as alterações eventualmente feitas ao longo do processo - na fase das comissões, por exemplo. Importante ressaltar que os casos foram escolhidos de acordo com a opção metodológica para o controle de variáveis e não compõem uma amostra aleatória. Por esse motivo, os resultados obtidos não poderão ser estendidos ao banco total, mas apenas ao próprio conjunto dos casos analisados referentes às coalizões. Em que pese essa restrição, acredita-se que o tamanho " $\mathrm{N}$ " em relação ao banco total permite uma visão razoavelmente confiável sobre o desempenho do Senado como Câmara revisora de propostas do Executivo no Brasil. Feitos os esclarecimentos, cabe expor as hipóteses:

O tamanho, a abrangência ideológica e o número efetivo de partidos da coalizão (NEPC), bem como o grau de incongruência bicameral intracoalizão, expressam cenários mais ou menos complexos para as negociações entre as Casas. Por hipótese, controladas outras variáveis relevantes, esses indicadores estão associados (negativa ou positivamente) à probabilidade de que os projetos sejam emendados no Senado. Especificamente: (a) espera-se uma relação negativa entre o status majoritário da coalizão e as chances de emendamento (consideradas em termos binários, de sim ou não) em revisão; (b) ao contrário, espera-se uma associação positiva entre os demais indicadores e o emendamento: (b1) quanto maior a abrangência ideológica da coalizão maiores as chances de emendamento em revisão; (b2) quanto maior o NEP da coalizão maiores as chances de emendamento em revisão; (b3) quanto maior divergência bicameral da coalizão maiores as chances de emendamento em revisão.

Adiante estão os modelos estatísticos produzidos para testar essas hipóteses. No Modelo 1 foram incluídas variáveis de controle consideradas importantes; no Modelo 2 foram adicionadas as variáveis explicativas. Os resultados mostram as chances percentuais de emendamento e devem ser lidos em relação às categorias de referência - regime de tramitação: ordinário; conteúdo das propostas: administrativo; tipo de proposição: projeto de lei ordinária; natureza do impacto esperado: não. federativo; governo: FHC. Isso posto, nota-se que o modelo de regressão logística elaborado esclarece pontos importantes sobre os fatores que afetam a disposição dos senadores para emendar os projetos. 
ARAÚJO, P. M. Bicameralismo e Poder Executivo no Brasil: revisão de projetos...

Tabela 6

Modelos de regressão logística:

bases do emendamento no Senado Federal, por coalizões

(1989-2010)

\begin{tabular}{|c|c|c|c|c|c|c|c|c|c|c|}
\hline & & \multicolumn{5}{|c|}{ Modelo 1} & \multicolumn{4}{|c|}{ Modelo 2} \\
\hline & & S.E. & Sig. & $\operatorname{Exp}(B)$ & \multicolumn{2}{|c|}{ chance } & S.E. & Sig. & $\operatorname{Exp}(B)$ & chance \\
\hline \multicolumn{2}{|l|}{ (Constant) } & ,803 & ,000 &, 000 & \multicolumn{2}{|c|}{. } & 1,173 &, 000 &, 000 & . \\
\hline \multicolumn{2}{|l|}{ Tramitação urgente } & ,348 &, 000 & $5,043 * * *$ & \multicolumn{2}{|c|}{404,3} &, 355 &, 000 & $5,002 * * *$ & 400,2 \\
\hline \multicolumn{2}{|c|}{ Tempo tramit. (log. natural) } & , 128 &, 000 & $2,463 * * *$ & \multicolumn{2}{|c|}{146,3} &, 132 &, 000 & $2,556^{* * * *}$ & 155,6 \\
\hline \multicolumn{2}{|c|}{ Conteúdo econômico } & ,352 &, 003 & $2,839 * * *$ & \multicolumn{2}{|c|}{183,9} & ,367 &, 002 & $3,183^{* * *}$ & 218,3 \\
\hline \multicolumn{2}{|c|}{ Conteúdo político } & ,969 & 063 & $6,045^{*}$ & \multicolumn{2}{|c|}{504,5} & ,980 & , 045 & $7,135^{* *}$ & 613,5 \\
\hline \multicolumn{2}{|c|}{ Conteúdo social } & ,312 & ,034 & $1,937 * *$ & \multicolumn{2}{|c|}{93,7} & ,323 & , 017 & $2,156 * *$ & 115,6 \\
\hline \multicolumn{2}{|c|}{ Lei complementar e PEC } &, 503 &, 544 & 1,357 & \multicolumn{2}{|c|}{35,7} &, 505 &, 512 & 1,393 & 39,3 \\
\hline \multicolumn{2}{|c|}{ Impacto federativo } &, 565 & ,419 & 1,578 & \multicolumn{2}{|c|}{57,8} &, 579 &, 521 & 1,451 & 45,1 \\
\hline \multicolumn{2}{|l|}{ Sarney } & ,642 &, 067 & $3,241^{*}$ & \multicolumn{2}{|c|}{224,1} & 1,182 &, 190 & 4,699 & 369,9 \\
\hline \multicolumn{2}{|l|}{ Collor } & ,356 &, 000 & $6,135 * * *$ & \multicolumn{2}{|c|}{513,5} & ,705 & ,004 & $7,740 * * *$ & 674 \\
\hline Itamar & & ,476 & ,385 & 1,512 & & 1,2 & ,625 & ,943 &, 956 & $.4,4$ \\
\hline Lula & & ,343 & ,092 & $1,784^{*}$ & & 3,4 & 1,106 & ,308 & ,324 & $.67,6$ \\
\hline Div. bicameral intra & coalizão & & & & & & ,397 & ,966 & ,983 & $\cdot 1,7$ \\
\hline NEP Coalizão & & & & & & & ,444 & ,676 & 1,204 & 20,4 \\
\hline Abrang. Ideol. da c & balizão & & & & & & ,466 & ,089 & $2,206^{*}$ & 120,6 \\
\hline Coalizão majoritári & & & & & & & ,627 & ,012 &, $209 * *$ & $.79,1$ \\
\hline Sumário dos & & & elo 1 & & & & & Mode & & \\
\hline & $\begin{array}{l}-2 \text { Log } \\
\text { likelihood }\end{array}$ & $\begin{array}{l}\text { Cox \& } \\
\text { Squar }\end{array}$ & $e / / R$ & $\begin{array}{l}\text { Nagelkerk } \\
\text { Square }\end{array}$ & & & $\begin{array}{l}g \\
\text { hood }\end{array}$ & $\begin{array}{l}\text { Cox \& S } \\
R \text { Squal }\end{array}$ & $\begin{array}{l}\mathrm{Nag} \\
\mathrm{Squ}\end{array}$ & $\begin{array}{l}\text { kerke } R \\
\text { e } \\
\end{array}$ \\
\hline & 410,810 & &, 145 & & 56 & & 02,138 & & 57 & ,277 \\
\hline
\end{tabular}

*** significativo em $0.01 ;{ }^{* *}$ significativo em $0.05 ; *$ significativo em 0,10

OBS: As razões de chance são calculadas pela fórmula: $[\operatorname{Exp}(B)-1] \times 100$. Os resultados do cálculo devem ser lidos em relação à categoria de referência e representam a probabilidade (\%) de emendamento decorrente da mudança em (um) ponto ou categoria na variável explicativa.

As variáveis de controle incluídas no modelo revelam fenômenos interessantes, mas que fogem ao objetivo específico deste artigo. A interpretação desses efeitos, à luz do arranjo bicameral brasileiro, foi objeto de análise em Araújo (2009). No tocante ao impacto das variáveis explicativas, a variável "divergência bicameral intracoalizão"18 gerou um índice contrário ao esperado: negativo, estatisticamente não significativo e virtualmente irrelevante em termos percentuais $(\cdot 1,7 \%)$. A variável NEP gerou um valor mais alto $(20,4 \%)$, com sinal positivo indicando que o fator de chance opera na direção prevista, mas o índice não é estatisticamente significativo.

A abrangência ideológica da coalizão mostrou o efeito esperado, significativo em 0,10. Assim, com 90\% de confiabilidade, pode-se afirmar que, controladas as demais variáveis usadas no modelo, cada ponto a mais que a coalizão ocupa no espectro ideológico aumenta em $120 \%$ a probabilidade de que o projeto seja modificado pelos senadores. A hipótese relativa ao tamanho da coalizão também foi

\footnotetext{
18 Para facilitar a leitura dos resultados em termos das razões de chance, os valores desta e da variável NEP da coalizão foram agregados e convertidos numa escala de três pontos, com valores 0,1 e 2. A variável abrangência ideológica da coalizão manteve seus valores originais, discretos, de 0 a 5 . A variável tamanho da coalizão foi dicotomizada (valores 0 e 1 , para coalizões minoritárias e majoritárias, respectivamente).
} 
confirmada, com sig. 0,05. Segundo o modelo, controladas as demais variáveis, os projetos têm $\cdot 79 \%$ de chances de serem emendados no Senado quando tramitam sob a proteção de coalizões majoritárias.

De acordo com os dados, a abrangência ideológica da coalizão deve ser levada em conta, pois, quanto maior a abrangência, maior a tendência ao emendamento e, por suposto, mais custosas as negociações políticas entre (ou com) os senadores. O status da coalizão também afeta as chances de emendamento: sendo majoritária, a base governista tende a assegurar a aprovação da forma original, intocada, das propostas de legislação apresentadas pelo Executivo - isso indica que o apoio da coalizão é um ingrediente de alto valor estratégico para o sucesso legislativo do governo no Senado, se tal sucesso for entendido como a capacidade de aprovar legislação da forma originalmente projetada.

Os índices relativos ao governo Lula apontam nesta direção. No Modelo 1, nota-se que suas propostas enfrentaram $78 \%$ mais probabilidades de serem alteradas pelos senadores, se comparadas com as de FHC (categoria de referência). No entanto, ao serem acrescentadas as variáveis explicativas relativas às coalizões, os valores e os sinais se modificam, indicando que, controladas as variáveis relativas às características da base governista, os projetos apresentados por Lula enfrentaram chances menores de emendamento do que as de FHC (-67,6\%, com 90\% de confiabilidade).

\section{Considerações Finais}

Este artigo analisou as bases políticas das decisões do Senado e propôs mensurar a incongruência do bicameralismo brasileiro, visando analisar seus efeitos no comportamento dos senadores relativamente ao processo legislativo na Casa. Para isso, analisou a evolução da representação político-partidária em escala bicameral, o que permitiu testar algumas hipóteses sobre suas consequências no funcionamento do Senado e na sua interação com a Câmara.

Os dados do período permitem concluir que as regras de representação adotadas no Brasil e as características do processo decisório federal tendem a criar condições para que o Senado seja uma arena menos complexa que a Câmara no tocante à formação de maiorias e à aprovação de leis dos projetos que tramitam na Casa - no caso, particularmente os do Poder Executivo. Isso ocorre, basicamente, por duas causas. Uma delas é que tanto o formato bicameral das coalizões quanto o da representação legislativa como um todo incorporam, no Senado, um número menor de atores, com um perfil ideológico mais moderado. Quando se trata das coalizões, além de terem sido menos fragmentadas entre os senadores e quase sempre majoritárias ao longo do período, elas compuseram, boa parte das vezes, bancadas maiores que na Câmara dos Deputados. A outra causa plausível supõe que, sendo o Senado uma casa revisora de todos os projetos menos os seus, os interesses ali representados podem ser antecipados nas deliberações da Câmara, de modo que os senadores só têm incentivos para atuar de forma contundente quando tais interesses não são devidamente atendidos nas etapas anteriores do processo de formação de leis.

Para testar as hipóteses relativas a essas questões, foram consideradas as conformações políticas das coalizões e foram avaliados os seus efeitos sobre as chances de um projeto ser emendado no Senado. O teste da hipótese sobre a divergência bicameral da coalizão produziu um índice de baixo valor e com sinal contrário ao esperado. $O$ teste relativo ao efeito do NEPC indicou associação na direção suposta, mas o índice não foi significativo. Diferentemente, as hipóteses relativas à abrangência 


\section{ARAÚJO, P. M. Bicameralismo e Poder Executivo no Brasil: revisão de projetos...}

ideológica e ao status da coalizão se mostraram válidas: coalizões ideologicamente mais abrangentes aumentaram as chances de emendamento, enquanto coalizões majoritárias reduziram tais chances em grau relevante.

A análise desenvolvida lançou luz sobre as bases do desempenho dos senadores no sistema bicameral. Por um lado, ficou claro que os condicionantes políticos e institucionais de funcionamento distanciam o Senado da ostensiva posição de veto prenunciada por certos especialistas; por outro, contra a imagem de casa carimbadora dos acordos fechados em outras arenas decisórias, pôde-se verificar que os mesmos condicionantes políticos, na medida em que variaram longitudinalmente, afetaram a disposição de veto por parte do Senado e mostraram os senadores como legisladores empenhados em afirmar seus interesses com os recursos institucionais de que dispõem.

\section{Referências Bibliográficas}

Abranches, S. "Presidencialismo de Coalizão: o dilema institucional brasileiro". Dados - Revista de Ciências Sociais, Rio de Janeiro, vol. 31, n’ 1, p. 5·38, 1988.

AMES, B. Os entraves da democracia no Brasil. Rio de Janeiro: FGV, 2001.

ANASTASIA, F.; INÁCIO, M. Notas sobre coalizões políticas e democracia: diz-me com quem andas... In: MeSSENBERG, D. et al. (orgs.). Estudos Legislativos: pensamento e ação política. Brasília: Câmara dos Deputados - Coordenação de Publicações, 2008.

Anastasia, F. e Melo, C. R. "A reforma da previdência em dois tempos". Dados - Revista de Ciências Sociais, vol. 48, n’2, p. $301 \cdot 332,2005$.

AndRade, R. C. (org.). Processo de governo no município e no estado: uma análise a partir de São Paulo. São Paulo: Edusp/Fapesp, 1998.

ARaújo, P. M. "O bicameralismo no Brasil: as bases políticas e institucionais do desempenho legislativo do Senado (1989-2004)." Belo Horizonte. 195p. Tese de Doutorado. UFMG, 2009.

"O bicameralismo no Brasil: argumentos sobre a importância do Senado na análise do processo decisório federal". Política \& Sociedade, vol. 11, n²1, p. 83-135, 2012.

"As eleições bicamerais e o perfil dos parlamentares no Congresso Nacional: candidatos eleitos e não eleitos

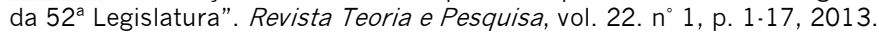

BACKES, A. L. "Democracia e Sobre-representação de Regiões: o papel do Senado." Brasília, 162p. Dissertação de Mestrado, UnB, 1999.

Fortalecimento parlamentar de minorias regionais e suas razões. In: LEMOS, L. B. (org.). O Senado Federal constituinte no Pós.Constituinte. Brasília: Senado Federal - Unilegis, 2008.

BARTOLIne S. \& MaIR, P. Identity, competition, and electoral availability. Cambridge: Cambridge University Press, 1990.

Cheibub, J. A.; Przeworski, A.; SAiEgh, S. M. "Government Coalitions and Legislative Success under Presidentialism and Parliamentarism". British Journal of Political Science, vol. 34, n’ 4, p. 565-587, 2004.

Coppedge, M. “The Dynamic Diversity of Latin American Party Systems”. Party Politics, vol. 4, n 4, p.549.570, 1998.

CARREIRÃO, Y. S. "Eleições e sistema partidário em Florianópolis: 1982-2004". Revista de Ciências Humanas, vol. 1, nं 40, p. 385.401, 2006.

Desposato, S. "Could SMD Solve Brazil's Political Problems? A comparison of the Brazilian Senate and Chamber of Deputies". Political Reform: Brazil in Comparative Perspective. IUPERJ, Rio de Janeiro, 27-28 jun. 2002. 
"The Impact of Electoral Rules on Legislative Parties: Lessons from the Brazilian Senate and Chamber of Deputies". The Journal of Politics, vol.68, n 4, p. 1015-1027, 2006.

DUVERGER, M. Os partidos políticos. Brasília: UnB, 1980.

FIGUeIREDO, A. "Formação, Funcionamento e Desempenho das Coalizões de Governo no Brasil". $5^{\circ}$ Encontro da ABCP, UFMG, Belo Horizonte, 2006.

e LIMONGI, F. “As reformas (des)necessárias". São Paulo em Perspectiva, n 10, p. 37.43, 1996.

Executivo e Legislativo na Nova Ordem Constitucional. Rio de Janeiro: Editora FGV, 1999.

Política Orçamentária no Presidencialismo de Coalizão. Rio de Janeiro: Editora FGV, 2008.

García-Diez, F.; Barahona, E. M. "La estratégia política e parlamentaria de los partidos de oposición latinoamericanos". Revista Instituciones y Desarrollo, n’12-13, 2002.

HIROY, T. "The Dynamics of Lawmaking in a Bicameral Legislature: the case of Brazil". Comparative Political Studies, vol.41, n`12, p.1583.1606, 2008.

INÁcıo, M." Presidencialismo de Coalizão e sucesso presidencial na arena legislativa 1990-2004." Belo Horizonte. 167 p. Tese de Doutorado. UFMG, 2006.

; Nuno, A. "Competição Política e Estabilidade sob o Presidencialismo de Coalizão na América do Sul". Revista Teoria e Sociedade. Número Especial, p. 12-45, 2005.

LIJPHART, A. Modelos de Democracia: desempenho e padrões de governo em 36 países. Rio de Janeiro: Civilização Brasileira, 2003

LINZ, J. Presidential or Parliamentary Democracy: does it make a diference? In: LinZ, J. J. e VAlenzUeLA, A. (eds.). The Failure of Presidential Democracy: the case of Latin America (vol. 2). Baltimore: The John Hopkins University Press, 1994.

LLAnos, M. "El bicameralismo en América Latina". Anuário de Derecho Constitucional Latinoamericano, vol. 3, n 1, p.347-377, 2003.

LLANOS, M. e Nolte, D. "Bicameralism in the Americas: around the extremes of symmetry and incongruence". The Journal of Legislative Studies, vol. 9, n³, p. 54-86, 2003.

MaInWARING, S. "Multipartism, Strong Federalism, and Presidentialism in Brazil". In: MaInWARING, S. e SHUGart, M. (eds.). Presidentialism and Democracy in Latin America. New York/Cambridge: Cambridge University Press, 1997.

Sistemas Partidários: o caso do Brasil. Rio de Janeiro: Editora FGV, 2001.

MAYHEW, D. Divided we govern: party control, lawmaking, and investigations, 1946-1990. New Haven: Yale University Press, 1991.

Melo, C. R. Retirando as Cadeiras do Lugar. Migração Partidária na Câmara dos Deputados (1985-2002). Belo Horizonte: Editora UFMG, 2004.

Melo, N. L. e BAtista, M. "Diferentes, mas iguais? Padrões de disciplina partidária na Câmara e no Senado". Revista Política Hoje, vol. 21, n 1, p. 150-185, 2012.

Meneguello, R. El impacto de la democratización del Estado en el desarrollo de los partidos brasileños. In: CavarozzI, M. e MEDINA, J. A. (orgs.). El asedio a la política: los partidos latinoamericanos en la era neoliberal. Rosário: Konrad. Adenauer/Homo Sapiens Ediciones, 2002.

MiRANDA, G. L. "A Influência da Dinâmica Eleitoral sobre o Comportamento dos Partidos na Câmara dos Deputados e no Senado Federal". Dados - Revista de Ciências Sociais, Rio de Janeiro, vol. 52, n 4, p. 911.959, 2009.

"A delegação aos líderes partidários na Câmara dos Deputados e no Senado Federal." Revista de Sociologia e Política, vol.18, n³7, p. 201-225, 2010.

NeIVA, P. R. "Coesão e Disciplina Partidária no Senado Federal". Dados - Revista de Ciências Sociais, vol.54, n², p.289-318, 2011.

NicolaU, J. Sistemas Eleitorais: uma introdução. Rio de Janeiro: FGV, 1999. 


\section{ARAÚJO, P. M. Bicameralismo e Poder Executivo no Brasil: revisão de projetos...}

PASQUARELLI, B. V. "Formação de coalizões, apoio legislativo e atuação partidária no presidencialismo brasileiro". São Carlos. 139 p. Dissertação de Mestrado, UFSCar, 2011.

REYNoso, D. "Sistemas electorales y composiciones partidarias bicamerales en Latinoamérica". Revista Ibero-Americana de Estudos Legislativos, vol. 1, n 1, p. 81-100, 2010.

RıcCl, P. A produção legislativa no Congresso: diferenças e similaridades entre a Câmara dos Deputados e o Senado Federal. In: LemoS, L. B. (org.). O Senado Federal no Pós.Constituinte. Brasília: Senado Federal, Unilegis, 2008.

RodRIGUES, L. M. Partidos, ideologia e composição social: um estudo das bancadas partidárias na Câmara dos Deputados. São Paulo: Edusp, 2002.

SANTOS, F. O Poder Legislativo no presidencialismo de coalizão. Belo Horizonte: Editora UFMG, Rio de Janeiro: IUPERJ, 2003.

; ALmeIDA, A. "Teoria Informacional e a Seleção de Relatores na Câmara dos Deputados". Dados - Revista de Ciências Sociais, Rio de Janeiro, vol. 48, n 4, p. 693.735, 2005.

Simão Branco, M. A Atuação do Senado Federal no Processo de Ajuste Fiscal dos Anos 90. In: Lemos, L. R. (org.). $O$ Senado Federal Brasileiro no Pós.Constituinte. Brasília: Senado Federal, Unilegis, 2008.

Stepan, A. "Para uma nova análise comparativa do federalismo e da democracia." Dados - Revista de Ciências Sociais, vol. 42, n², p. 00-00, 1999. Disponível em <http://www.scielo.br/scielo.php?script=sci_arttext\&pid=S0011. $52581999000200001 \&$ lng=en\&nrm=iso>. Acesso em: 17 jul. 2013.

TSEBELIS, G. "Processo decisório em sistemas políticos: veto players no presidencialismo, parlamentarismo, multicameralismo e pluripartidarismo." RBCS, vol. 12, n³4, p. 00-00, 1995. Disponível em <http://portal.anpocs.org/portal/index.php?option=com_docman\&task=doc_download\&gid=28\&ltemid=203>. Acesso em: 13 jul. 2013.

Jogos Ocultos: escolha racional no campo da política comparada. São Paulo: Edusp, 1998.

e Money, J. Bicameralism. Cambridge: Cambridge University Press, 1997.

Paulo Magalhães Araújo - pmagal@uol.com.br

Submetido à publicação em outubro de 2012. Versão final aprovada em julho de 2013. 